\title{
Achieving Developmental and Pro-Poor Trade in Africa: the Mauritian Transition- Emerging-Economy: Success Case Study-Initiatives, Innovations and Incentives
}

\author{
Rajendra Parsad GUNPUTH \\ University of Mauritius, Mauritius \\ rpgunput@uom.ac.mu
}

\begin{abstract}
In a contextualized approach the author explores development achievements in terms of propoor trade in Mauritius and to its transition-economy. Indeed, Mauritius is very notorious for its aggressive economic and financial lobbying specially on the African continent coupled to its openness strategy, easy-doing business with implementation of various national and strategic policies (development of its Freeport harbours and Export Processing Zone (EPZ), offshore sectors with massive foreign direct investment (FDI), development of the BPO and ICT sector in the Cyber City, diversification of the Mauritian export from sugar to industrial goods with major development in some emerging sectors such as trade in services through the tourism industry which is now contributing up to 8\% of its GDP with massive employment in its hotels and construction, and Mauritius is actually targeting to exploit its exclusive economic zone) to increase both its imports of raw materials and exports of goods. Furthermore, it is a member of various regional economic blocks in the region (COMESA, SADC, IOR) to attract African investors and to bridge China and India to the African continent. All these strategies, factors and polices including strategic importance of Mauritius have contributed to trade diversification which in turn has created jobs to combat poverty eradication in a wealthier nation so far. Data to reflect and/or to prove same are borrowed mainly from the Central Statistics Office (CSO) in Mauritius, the Board of Investment in Mauritius (BOI), UNCTAD and the Bank of Mauritius Annual Reports principally during the period 2001-2012. The paper, with facts and figures, reflects to what extent achieving developmental and poor-trade is possible on the African continent. Is the Mauritian economy a reliable model? Why is it so wealthy actually or whether its economic miracle has been a mere luck up to now?
\end{abstract}

Keywords: Transition economy, Foreign Direct Investment, emerging sectors, financial sector

\section{Introduction}

Inspiring from a Westminster model of democracy since its independence in 1968, non-economic indicators such as political and social stability, good governance and good management in the private and public sector, know-how, free education since 1977 (adult literacy rate is 80\%) and free transport to all tertiary students, free health care and other social welfare benefits, have contributed to the economic development of the country backed up by important national and strategic policies. The Constitution of Mauritius, the supreme law of the land, is a written Constitution, which eminent British law professors have legally drafted, contains human rights, powers of the Supreme Court and right to appeal to the Judicial Committee of the Privy Council and other sections deal with the Prime Minister, the President of the Republic, the Leader of Opposition, election just to name a few. All national policies as well as new bills are discussed thoroughly so that everyone has a role to play in implementing ideas and suggestions in a democratic manner. The Mauritian legislator borrows legislations from UK principally to implement same in our statutory books. Whatsoever, import and export policies cannot operate in a vacuum. Most countries need investors but there must be incentives (information, security, innovations) to attract them to work in decent and healthy financial conditions. In addition, a strong legal and institutional framework must be in operation so that laws of the country are clear and that institutions in the country are reliable, unbiased and properly administered and managed. In Mauritius, support comes from different ministers, which are very motivated to promote and facilitate foreign direct investment (FDI) in key and emerging sectors (SMES, tourism, service sector) of the Mauritius economy for example.

The question of developmental and pro-poor trade is relevant for a country such as Mauritius, which is rather rare for a country which was both under both French (1715-1810) and British colonisation (18101968), and which obtained its independence without any single bloodshed. Relying solely on sugar since its independence in 1968 and the agriculture sector in the 70's, in a country where unemployment was high, but a quick radical diversification in Mauritius with the development of emerging sectors (EPZ with 
low labour cost-Table 1), financial sector, tourism sector, development in its banking and financial sector, FDI) contributing to a massive job creation in the hotel sector and ICT-BPO sector such that Mauritius has to rely on expatriate workers (India, China, Taiwan, Bangladesh) in the textile and manufacturing sector. If foreign investors like risks they have never hesitated to settle business in this small country of 1866 square kilometres with a population of about 1,28 million inhabitants of different origins and culture. Its strategic position in the Indian Ocean (Map 1), its political and socio-economic stability also account for its success in a small island where people are relatively more pacific than elsewhere. (seemap and its Strategic position of Mauritius in the Indian Ocean.

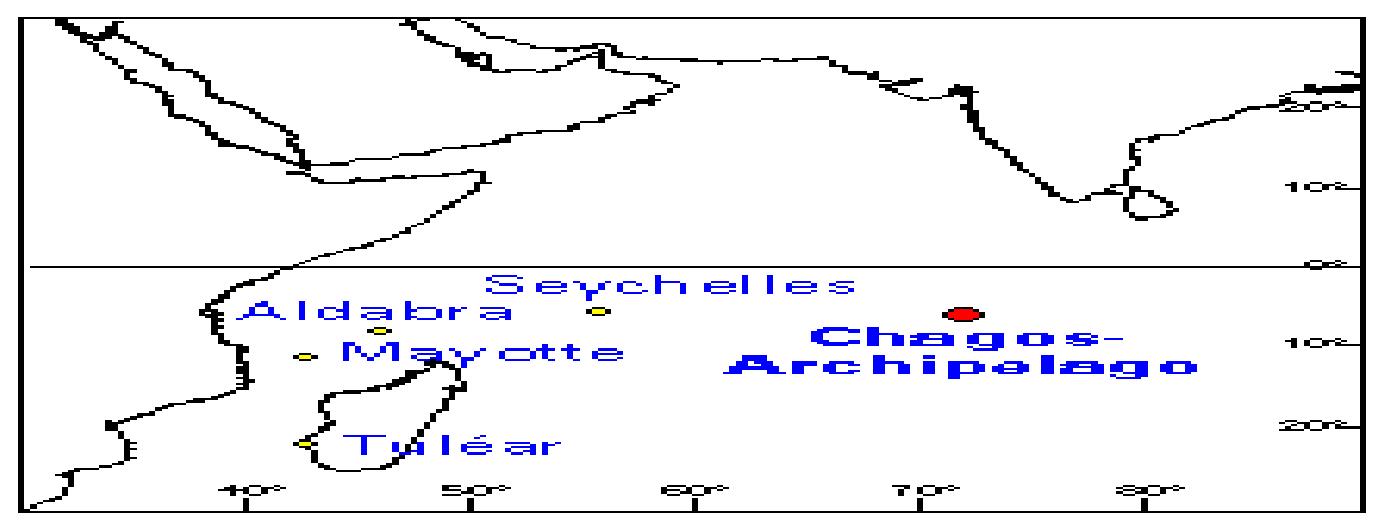

Source: website).

Major developments took place by the late 1980s and early 1990s: the Mauritian economy significantly reduced its dependence on agriculture and became more diversified with major developments in the services sector which has been earmarked as the area for economic development. To boost emerging sectors in Mauritius new legislations (The Banking Act was amended in 1988 to enable offshore banking to be carried out, establishment of the Stock Exchange Act 1988 to provide for the setup of a supervisory body and a private operating and management company, measures were therefore enacted to provide a new thrust to the development of financial services and economic development in Mauritius culminating in 1994 with the abolition of the exchange control, The Mauritius Offshore Business Activities Act and the Offshore Trusts Act were enacted in 1992 to deal with non-banking offshore business activities in Mauritius, and the establishment and the development of a Freeport in 1992 to follow the economic development strategy of Mauritius and to position it as a financial , business and trading hub in the Indian Ocean region).

Mauritius is so successful in its export and import without any competitive devaluation, or a very small one to boost imports and importation of goods, of its national currency (rupees) to enhance trade while some African countries did a very aggressive use of devaluation (of the FCFA) as an export-enhancing device. Major events in its poor-trade development are:

1.1968. Independence. Mauritius relies on sugar and agriculture to survive

2. 1970. Emergence of the EPZ sector with massive exportation of cloth to Europe until the African Growth and Opportunity Act (AGOA) came into operation to support this dying sector another boost

3. 1980. Double Taxation Avoidance Agreement (DTAA) with 34 countries to attracts FDI

4. 1990. Industrial Expansion Act 1993 came into force

5. Trade, business and investments need pillars to stand and in a nutshell the following pieces of legislations have been implemented to secure and encourage fair trade in the country with foreigners who wish to settle in the country: The Fair Trade Act, Business Registration Act 2002, Cooperatives Societies Act 1976, Investment Promotion Act 2000, Cooperatives Act 2005, Bills of Exchange Act 1914, Income Tax Act 2005, Companies Act 2001, Protection against Unfair Practices (Industry Property Rights) Act 2002, Prevention of Corruption Act 2000, Financial Intelligence and Anti-Money Laundering Act 2002, Prevention of Terrorism Act 2002, Financial Reporting Act 2004 just to name a few. The main Acts which are linked with trade in Mauritius are the Customs Tariff Act 1969, Customs Act 1988 and its regulations, Consumer Protection Price and Supplies Control Act 1988, Value Added Tax 1998 just to name a few. Under the aegis of the Mauritian Government various trade policies and institutions (Mauritius Revenue Authority, Export Processing Zone Development Authority, Industrial and Vocational Training Board, Mauritius Chamber of Commerce and Industry, Mauritius Export Development and investment Authority, Mauritius Processing Zone Association, Mauritius standard Bureau, Small and Medium Industries 
Development Organisation) /ministries (Ministry of Finance and Economic Development, Ministry of Foreign Affairs, International Trade and Cooperation) have been set up promptly to control trade and businesses in Mauritius so that everybody can trade free and fairly with equal treatment enhancing social and cultural integration.

6. In its 2006-2007 budget, Mauritius seems to be in line with its liberal investment policy and strategy avoiding economic or industrial strategies, which may eventually discriminate foreign investors. For example Mauritius has abolished exchange controls since 1994,100\% foreign ownership is allowed, registration duties are at $5 \%$ only, even one share holder company is permissible, a company may be incorporated in 24 hours, preferential market access in COMESA, SADC and AGOA, access to Double Tax Treaties (India), most of its institutions are empowered to take any administrative decision under an enactment and its judiciary is reliable and its decisions, totally impartial.

7. In 2009, introduction of an Act of Parliament The Corporate and Social Responsibility Act to encourage business organisation to give $2 \%$ of their dividends to contribute to sustainable economic development. As from 2010 Islamic banking became a new area for exploitation encouraging foreign investors to invest and to take loans without interest.

In addition to existing institutions (supra), a large number of public institutions (Board of Investment, Bank of Mauritius, Business Parks of Mauritius Ltd, Development Bank of Mauritius, Mauritius Industrial Development Authority, Export Processing Zone Development Authority, Financial Services Commission, Mauritius Promotion Tourist Authority, Mauritius Revenue Authority, State Investment corporation, National Productivity and Competitiveness Council just to name a few) have been set up to give support to trade, promotion and facilitating foreign direct investment in most of the keys sectors of the Mauritian economy. The chart below shows the sectoral breakdown of the Mauritian economy.

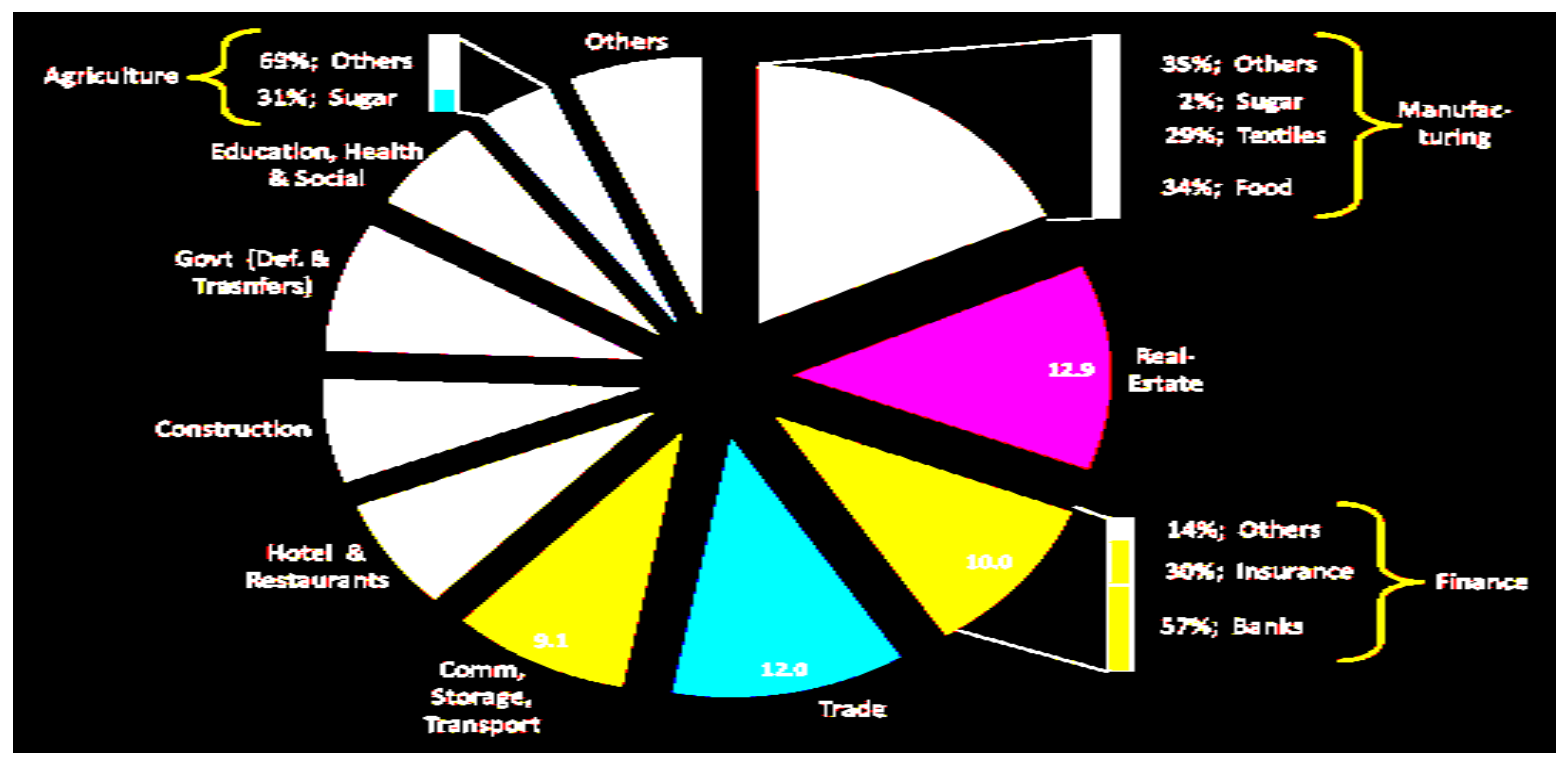

Source: Axys Stock broking Ltd (February 2012)

Mauritius also has to be competitive with other neighbouring countries and which are also members of different regional economic partnership agreements (South Africa, Mozambique, Seychelles). True is it that South African products are less expensive and eventually more competitive on the Mauritian markets once the South African Rands are at its lowest rate. It has never been denied that volatility in exchange rate could dampen economic growth as it would raise the costs of transacting in international trade and capital flows. Exchange rate volatilities may have a domino effect generating large-scale crisis. The Mauritian rupee, too, has devaluated rather frequently but nonetheless it is stabilised by a permanent growth in its GDP and above all its EPZ sector, ICT-IBO sector, financial and banking and tourism sector are expanding exponentially (and by as from 2012 Mauritius shall be ready to welcome a quantum of 2 million tourists annually). In Mauritius, compared to some other African countries, the private sector also plays a very important role and various private institutions (Mauritius Chamber of Commerce and Industry, Mauritius Export Processing Zone Authority, Joint Economic Council) have improved the industry development and trade services in the country either by giving support to the public sector or by 
contributing financial services in the banking sector. The potential of Mauritius to export in the subSaharan region must not be overlooked. In fact, countries may exploit the knowledge based on its past and actual experiences and development in the region to achieve success. In a competitive world it is time for African countries, like the rest of the world, to be more performant in regional and international trade. The Mauritian success is not a miracle which other members of the African regional block would not able to achieve. They, too, they have potentials and goods and services to share and export to increase the goodwill of a country but the question is how? By the way are there other alternatives to neoclassic economics theories for Africa? Table 1 summarises the economic performance of Mauritius on the African continent.

Table 1: Economic performance of Mauritius

\begin{tabular}{|c|c|c|}
\hline Performance & Number of countries & $\begin{array}{l}\text { Africa Rank- } \\
\text { Mauritius }\end{array}$ \\
\hline Environmental Performance Index 2010 & 6 out of 163 countries & 1 st \\
\hline $\begin{array}{l}2012 \text { Heritage Foundation Index of Economic } \\
\text { Freedom }\end{array}$ & 8th out of 183 countries & $1 \mathrm{st}$ \\
\hline Fraser Institute Economic Freedom 2011 & 9 out of 141 countries & $1 \mathrm{st}$ \\
\hline Forbes Survey of Best Countries for Business 2011 & 19 out of 134 countries & $1 \mathrm{st}$ \\
\hline World Bank Ease of Doing Business 2012 & 23 rd out of 183 countries & $1 \mathrm{st}$ \\
\hline Democracy Index 2010 & Full Democracy & $1 \mathrm{st}$ \\
\hline Global Enabling Trade Index & 24th out of 167 & $1 \mathrm{st}$ \\
\hline Knowledge Economy Index & 64 & $1 \mathrm{st}$ \\
\hline Mo Ibrahim Index of African Governance 2011 & --------------------- & 1 st \\
\hline International Property Rights Index 2011 & 38 out of 129 & 2nd \\
\hline Global Competitiveness Index 2011-2012 & 54 out of 142 countries & 2nd \\
\hline Africa Competitiveness Index 2011 & -------------------- & 2nd \\
\hline $\begin{array}{l}\text { Corruption Perceptions Index } 2010 \text { (Transparency } \\
\text { International) }\end{array}$ & 39 out of 178 & 2nd \\
\hline $\begin{array}{l}\text { ITU-United Nations Agency for Information and } \\
\text { communications }\end{array}$ & 62 nd out of 178 & ---- \\
\hline ITU's Digital Access Index & ------------------- & 2nd \\
\hline Outsourcing Readiness Index (Africa) 2009 & 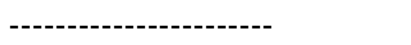 & $2^{\text {nd }}$ out of 15 \\
\hline Human Development Index 2011 & 77 out of 189 & $3 r d$ \\
\hline The A.T. Kearney Global Services Location Index, 2011 & 36 out of 50 countries & 4th \\
\hline
\end{tabular}

Source: author

Rome was not built in one day and the Mauritius economic miracle cannot be summarised in a few lines. With facts and figures, and through various proposed alternatives, the author tries to explain the specificities of the small island nation which most African countries do not have the privilege to enjoy (Welfare State, low unemployment growth, good social security and lumped pensions, openness to the world, political and social stability, domestic market growth with improvement in the private sector and exponential growth of the informal sector such as small and medium enterprises-SMEs, intra-regional development, and with Mauritius being a member of most regional economic partnership agreements just to name a few). After an introduction (1), this paper is structured into five main parts. The second provides for the opening up of the financial sector especially of the Mauritian offshore banking to attract foreign direct invest (FDI) in the small island nation. The third part deals with regional integration of Mauritius in various economic regional partnerships agreements (REPAs) and various emerging economic blocks followed by some solutions against poverty eradication in Mauritius and the fourth and final section looks briefly in the development of Islamic banking in Mauritius. Some recommendations and a conclusion will finally close the chapter. A reference will list some authors and their books they have authored or co-authored to guide researchers in their work.

\section{Openness of the financial sector in Mauritius and its Role in Poverty Reduction}

Trade performances in the Emerging Sectors (EPZ, ICT-BPO, FDI): Radical diversification in Mauritius and its impact on its domestic financial sector: Trade performances have been achieved following a radical diversification in Mauritius that has provoked a shift from agriculture to its export processing zone through development in the openness of its financial sector with rather cheap labour costs (Table 2). 
Table 2: Labor Costs Comparison

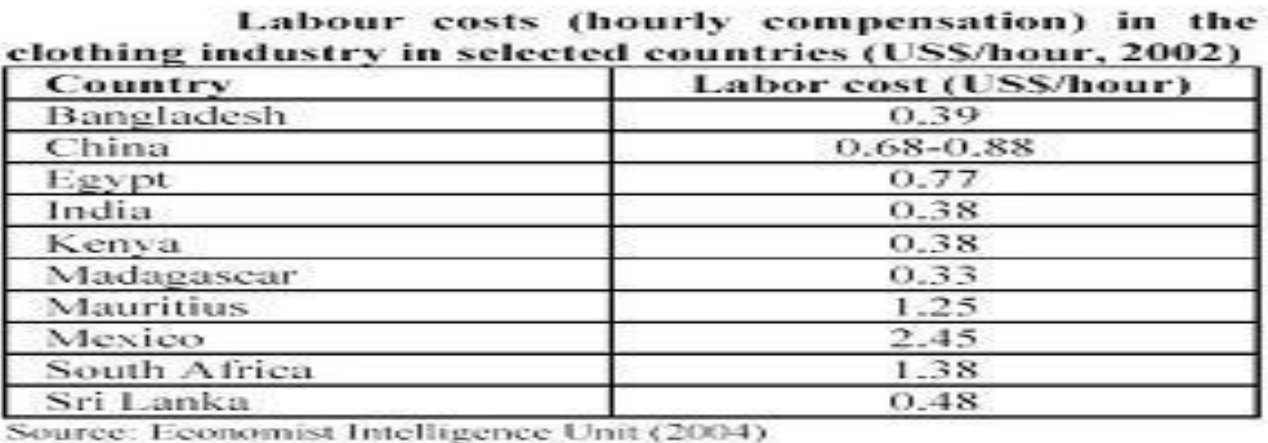

Source: Economist Intelligence Unit (2004)

In 1970, the Export Processing Zone Act came into force and the Export Processing Zone Programme spearheaded the favourable FDI flows in mid 1980's attracting foreign investors (India, China) to use Mauritius as a platform (its relatively cheap labour force is accountable for this-Table 2 and Figure 2) locating both textile and garment manufacturing operations to benefit in return preferential access to European and United States markets. Countries with abundant cheap and skilled labour, electricity and energy with improved infrastructures such as road, port facilities, telephone and internet might significantly reduce the cost of doing business, as compared to if they had to bear the cost of improving infrastructure before setting up business in the country (Khondoker and Kaliappa, 2010). As Gilles Joomun ${ }^{1}$ rightly pointed out: The success of the textile and clothing sector is partly attributed to factors besides the control of Mauritian authority. Some of the factors which have contributed positively to the Mauritian economy, in particular the textile and clothing sector are: the Multi-Fibre Agreement signed in 1982, which constrained several countries in their exports. It is in this context that investors from Hong Kong came to set up their firms in Mauritius. A combination of lower and falling oil prices together with a lower debt servicing arising due to the depreciation of the overvalued US dollar in 1984. An appreciation of the Taiwanese dollar and thereby a fall in Taiwan's competitiveness on world market led to Taiwanese investment in Mauritius. After 1984, appreciation of the European currencies in relation to the Mauritian rupee resulted in Mauritian goods becoming more competitive. During 1990s, political uncertainty over the future of Hong Kong's reintegration into China encouraged investors to look for a safer heaven and thus relocated to Mauritius bringing capital, market networks and technological know-how.

Nobody would have expected that whilst the Mauritian economy was shifting swiftly and rapidly from an agricultural sector (sugar, tea, tobacco, coffee) to a very diversified economy including agro-industry, export-oriented manufacturing, construction, tourism, financial services (offshore and free port services) and the ICT-BPO sector the small island nation of Republic of Mauritius would be so successful with an outstanding economic performance creating jobs (Figure 4) for one and all and contributing to the welfare of the small island nation.

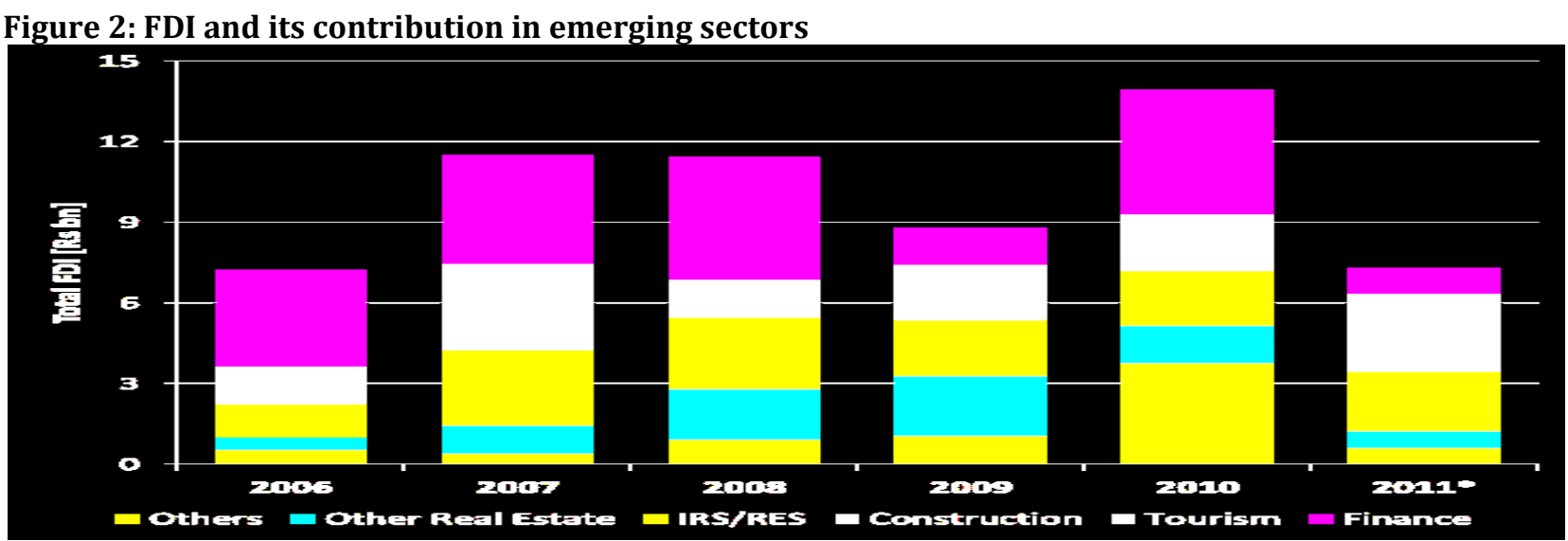

Source: CSO (2006-2012)

${ }^{1}$ Joomun G. 2006. 'Textile and clothing industry in sub-Saharan Africa', The future of the textile and clothing industry in sub-Saharan Africa (Bonn: Friedrich-Ebert-Stiftung). 
With fierce international (from Brazil, Bangladesh, Pakistan, India) and regional competition (from Mozambique) the textile and sugar sectors were not very competitive and Mauritius opened its gates to Indian offshore companies which were more specialized in the ICT-BPO sector (Figure 3) and other management companies which expanded very rapidly generating income. Very rapidly, the spectre of high rate unemployment slowed down showing significant progress in the Mauritian government to fight against unemployment and poverty eradication (Table 2, Table 3 and Figure 3). The sustainability of moderate or low inflation tells investors how successful the host government is, which means that, the lower the average inflation rate is in the host country, the more FDI will be attracted to the country (Yuko and Nauro, 2002).

Table 3: Inflation rate (\%) of selected countries, year 2011

\begin{tabular}{|c|c|c|c|}
\hline Country & $\begin{array}{l}\text { Inflation rate } \\
(\%)\end{array}$ & Country & $\begin{array}{l}\text { Inflation } \\
\text { rate (\%) }\end{array}$ \\
\hline France & 2.3 & Australia & 3.4 \\
\hline United Kingdom & 4.5 & United States & 3.1 \\
\hline China & 5.4 & Botswana & 8.5 \\
\hline India & 8.6 & Mauritius & 6.5 \\
\hline Japan & -0.3 & Seychelles & 2.6 \\
\hline Singapore & 5.2 & South Africa & 5.0 \\
\hline
\end{tabular}

Source - World Economic Outlook database, April 2012

According to the Central Statistics Office of Mauritius, the Consumer Price Index stood at 130.4 in December 2011 against 124.4 in December 2010 that is a 6.0 point increase or $4.8 \%$ increase. The headline inflation rate (that is the average inflation over the year) for the 2011 stood at $6.5 \%$ as compared to $2.9 \%$ in 2010 (Table 3). Despite this rise, the inflation rate remains below the $9.7 \%$ peak registered over the decade (see also Table 3 and Figure 3).

Figure 3: \% change in CPI sub indices between March and June 2012

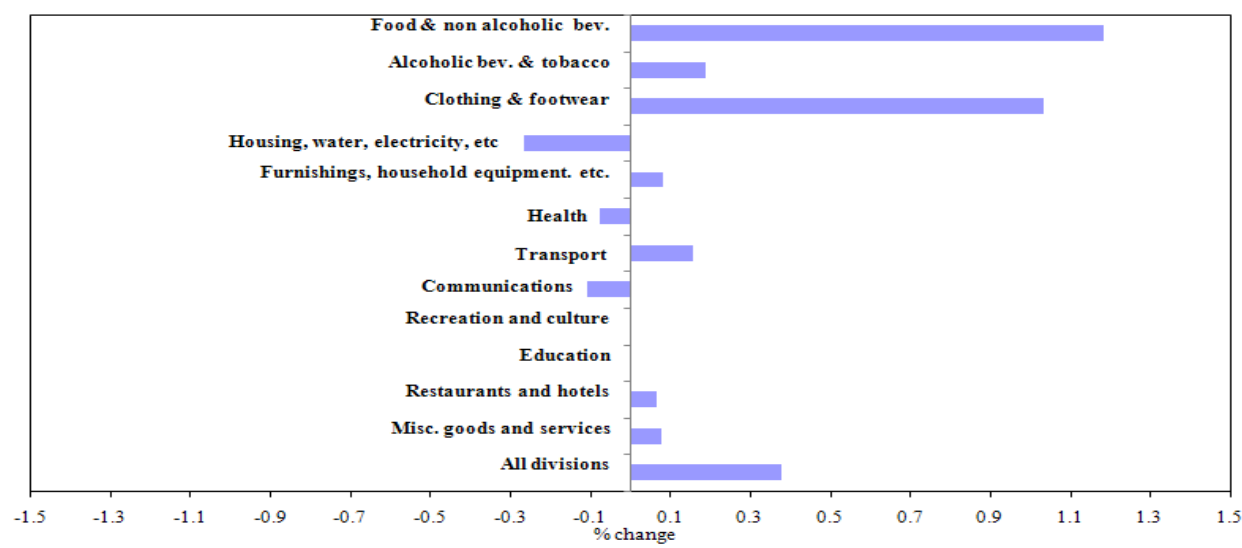

Figure 4: Rate of employment and unemployment (2007-2012)

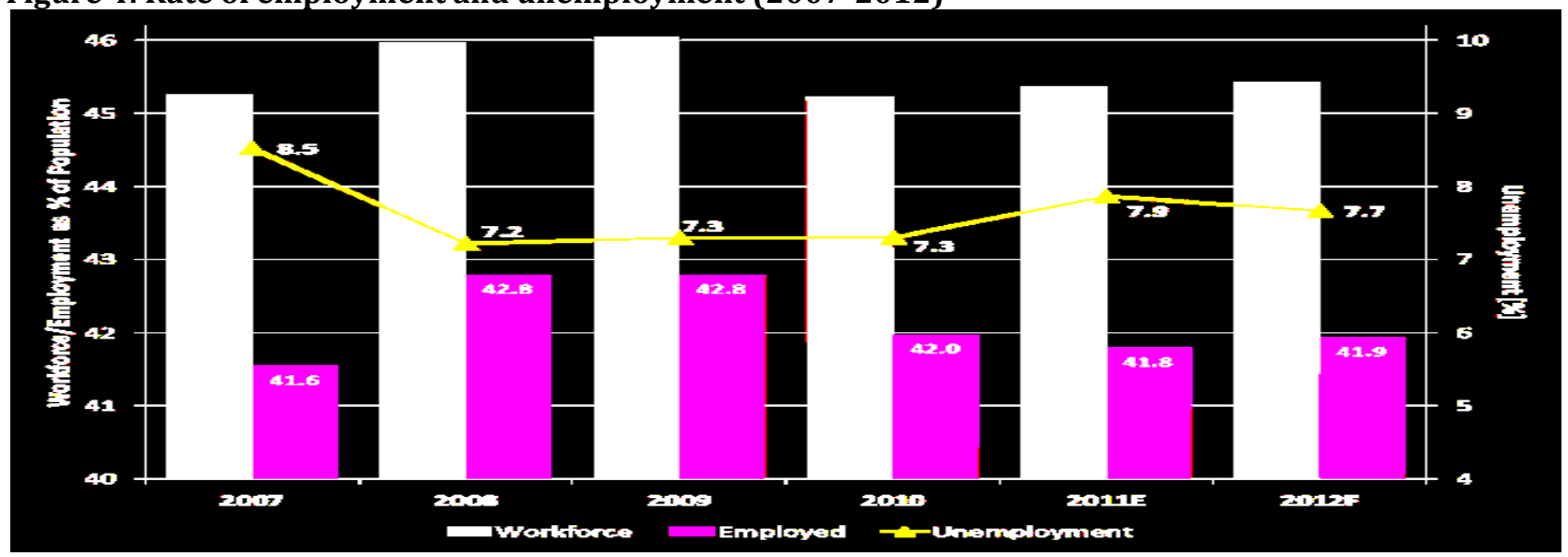

Source: CSO 
It is important to point out that for poor-trade development Mauritius remains a Welfare State where various institutions (hospitals, primary and secondary schools and transport companies) provide free services and the government is always ready to subsidize various products to maintain prices reasonable, unemployment rate Is kept low as well (Figure 4) and goods remain affordable to one and all in spite of inflation or in the event of any unexpected euro crisis.Over and above, it is also contributing to the welfare of other countries. For instance, Mauritius has signed and ratified double-taxation avoidance agreement (with India for example) to improve its financial sector contributing to $44 \%$ of India's foreign direct investment amounting to 40 billion dollars! Mauritius has already signed and ratified some 34 Double Taxation Avoidance Treaties, and one very recently with Kenya, and is contributing to 44\% of India's foreign direct investment (FDI) accounting for 50 billion dollars. From the year 2000 to 2009, the largest source of FDI in India is from Mauritius, representing around 44\% of total flows ${ }^{2}$. Prompted FDI stabilises not only the Mauritian EPZ but creates new avenues for development in other emerging sectors as well (Figure 5) such as the tourism sector.

\section{Figure 5: Emerging sectors}

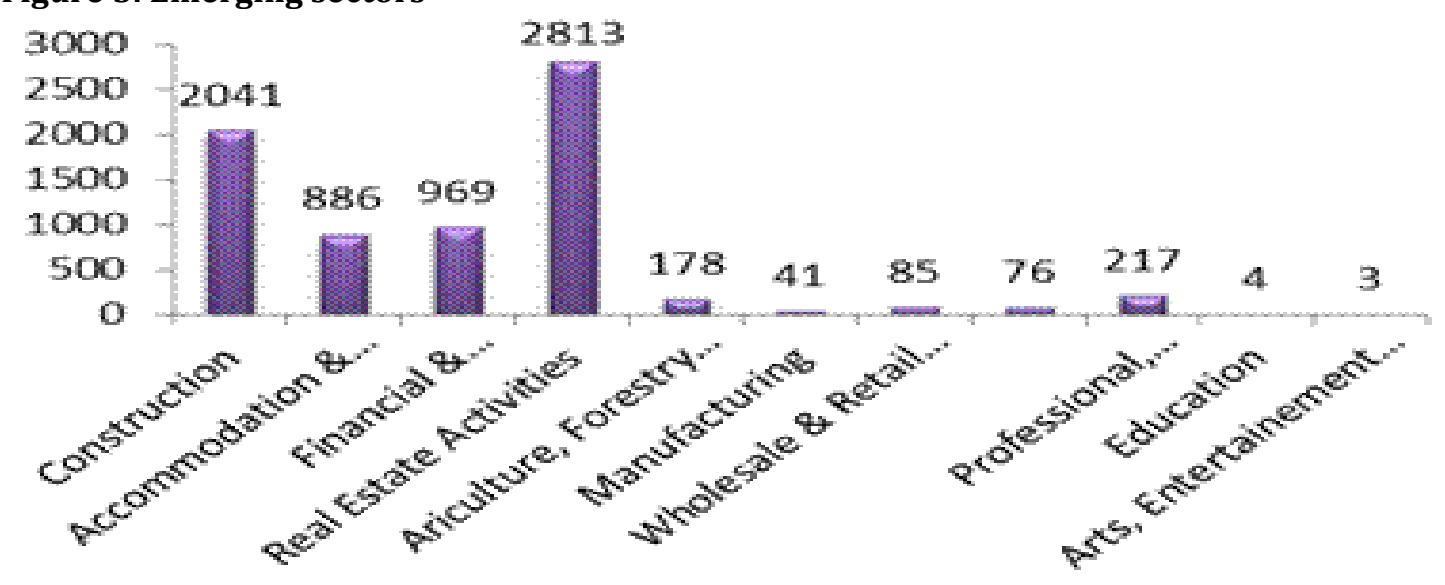

Source: CSO (200-2012)

Table 4: Economic Indicators

\begin{tabular}{lcccc}
\hline & $\mathbf{2 0 0 6}$ & $\mathbf{2 0 0 7}$ & $\mathbf{2 0 0 8}$ & $\mathbf{2 0 0 9 - 2 0 1 0}$ \\
\hline GDP at basic prices in Rs billion & 182 & 207 & 234 & 249 \\
GDP real growth rate (\%) & 5.1 & 5.5 & 5.3 & 2.5 \\
Per capita GDP at basic prices & & & & \\
inRs billion & 145 & 164 & 184 & 195 \\
Unemployment rate (\%) & 9.1 & 8.5 & 7.2 & 8.0 \\
Inflation rate (\%) & 5.1 & 10.7 & 8.8 & 6.9 \\
Investment rate (\% of GDP) & 24.3 & 25.1 & 24.6 & 24.4 \\
Budget deficit (\% of GDP) & 5.3 & 4.3 & 3.3 & 3.9 \\
\hline
\end{tabular}

Source: Central Statistics Office (CSO) during the period 2006-2010

In return Mauritius is benefitting from Indian offshore companies and since the beginning of the offshore sector in Mauritius, many management companies have been mushrooming on the island creating employment and most of these companies rely heavily on investments and trade pursuant to the DTA with India. Further agreements have been reached to avoid round tripping and treaty shopping. Actually, according to the Central Statistics Office (CSO), the financial sector is contributing approximately $11.6 \%$ to the Gross Domestic Product (GDP). Eventually, it has recorded an average GDP growth (Table 4) between 4\%-5\% whilst between 1968-1980 (a reign of restrictive and protectionist trade policy), the economy of the country was very unfortunately stagnant with tariffs barriers as high as $600 \%$, quantitative restrictions were imposed, strikes, high unemployment rate and an undiversified economy relying solely on sugar exports, which became too dependent of the European market. According to CSO the services sector not only provides more employment but also the highest average pay that is Rs 19,660 against Rs 11,704 for the secondary sector and Rs 12,426 for the primary sector. The subsector with the highest average earnings is electricity and water supply with Rs 24,945 while the subsector with the

\footnotetext{
${ }^{2}$ Source: Department of Industrial Policy and Promotion of India, Ministry of Commerce. http://dipp.nic.in
} 
lowest average earnings is textiles with only Rs 8,274. A handful of factors have contributed to this success including IMF and World Bank structural adjustment coupled with the stability of the local currency, development of the Export Processing Zone (EPZ), the tourism sector with massive arrivals from South Africa, India, China- Figure 5 and Table 6, liberal trade policies, coupled with trade preferences and a pro-business government have inevitably boosted the economy of the country. New pieces of legislations were passed to boost the financial sector.

Figure 6: Monthly Tourist Arrivals, January - June of 2011 and 2012

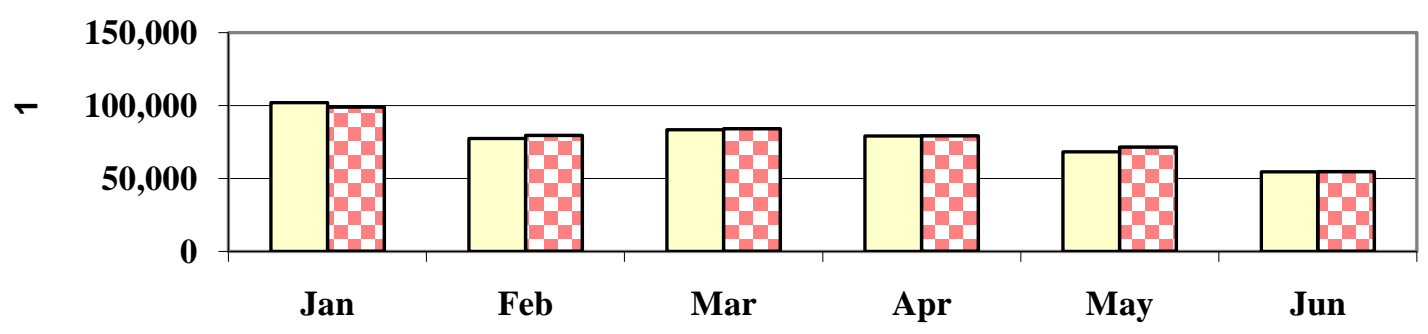

Source: CSO

The tourism sector is also expanding with tourist arrivals from India, China, South Africa and Europe. Table 5 illustrate tourist arrivals and gross earnings

Table 5: Tourism: arrivals and gross earnings

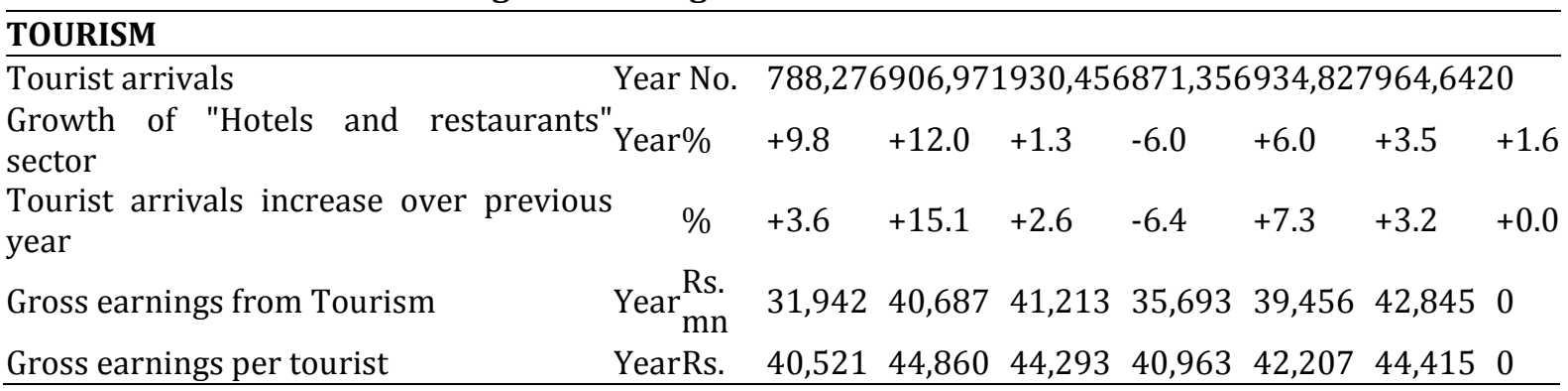

Source: Ministry of Finance and Economic Development. 2012

EPZ exports remain in Mauritius very promising (Table 6 and Table 7). By the end of December 2007, the number of enterprises in the EPZs totalled 404, employing 67,314 people among whom 32,973 were foreign workers from mainly China, India, Sri Lanka, and Bangladesh ${ }^{3}$.

Table 7: EPZ Exports, EPZ Exports and imports 1985-1995

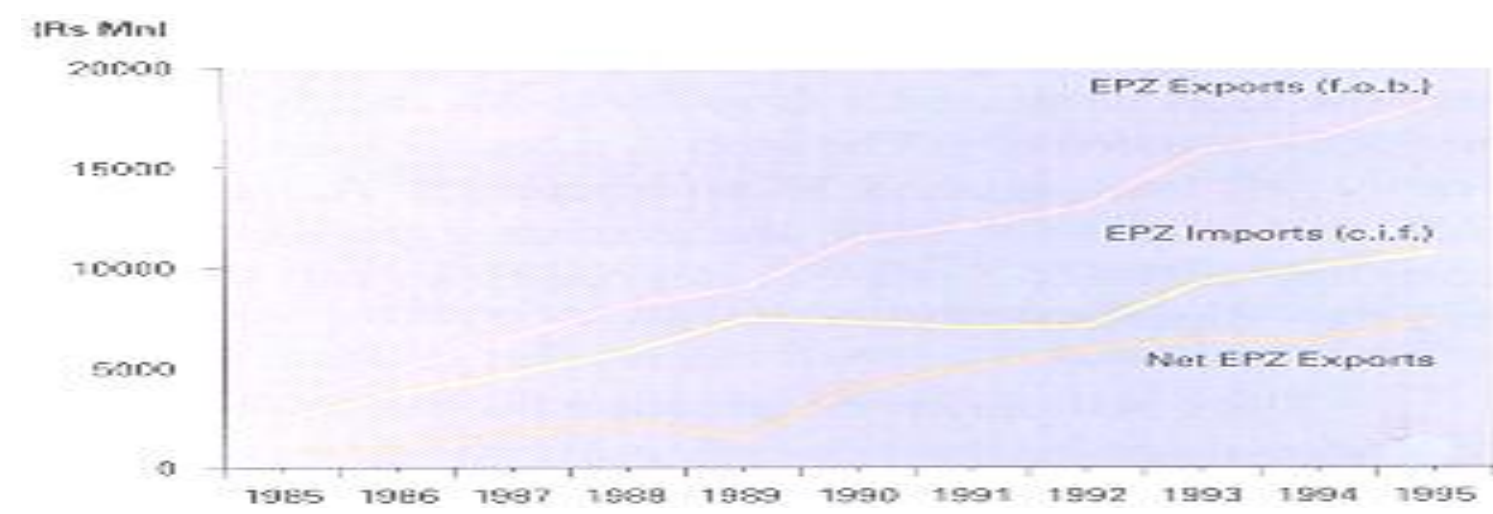

Source: Export Processing Zones Development Authority

\section{Table 8}

\footnotetext{
${ }^{3}$ allAfrica.com
} 


\begin{tabular}{|c|c|c|c|c|c|}
\hline $\begin{array}{c}\text { Exports } \\
(\text { to.t. } R s \mathrm{~m})\end{array}$ & 2001 & 2002 & 2003 & 2004 & 2005 \\
\hline $\begin{array}{l}\text { Totd Exports (donedic } \\
\text { q reesports) }\end{array}$ & 47,511 & 53,893 & 53,022 & 55,223 & 27,775 \\
\hline Epl & $33,69.5$ & 32,663 & 31,444 & 32,370 & 14,247 \\
\hline Textile & 28,099 & 26,540 & 28,814 & 28,165 & 12,147 \\
\hline Net Exports & 16,555 & 15,774 & 15,865 & 15,160 & $\mathrm{NA}$ \\
\hline
\end{tabular}

Source: CSO and Stock Exchange of Mauritius. 2001-2005

Trade Policies and policy making decisions to enhance the Mauritian economy: Mauritius has been exporting sugar since its independence in 1968. It has witnessed a very drastic reduction of $36 \%$ in price obtained for its sugar with the expiry of the Sugar Protocol under the LOME Convention. In fact it is the policy of the government to find new issues to new problems urgently and promptly in order to compensate for the loss.

a. Mauritius specificities for marketing in trade: In order for Mauritius to create jobs, establish schools and give education facilities to one and all in a country where primary education and secondary education is free as well as health services it needs money, funds and foreign investors. And relying on its specificities (small isolated island with no frontiers and borders, isolated island economy with diversified ethnic groups, small growing demography, landscapes which are ideal for tourism, low illiteracy and no natural resources such as gold and silver except to its blue economy) Mauritius opted for free and fair trade, regional trade, encouraged non-tariff barriers and import quotas and foreign exchange policing, lifted price controls, eliminated export licensing, abolition of export licensing just to name a few so that all Mauritians have each a share in the wealth of the country eliminating discrimination among the population when it is understood that the small island nation is rich in cultured diversity.

\section{Figure 9: Emerging trends of FDI-Emerging sectors}

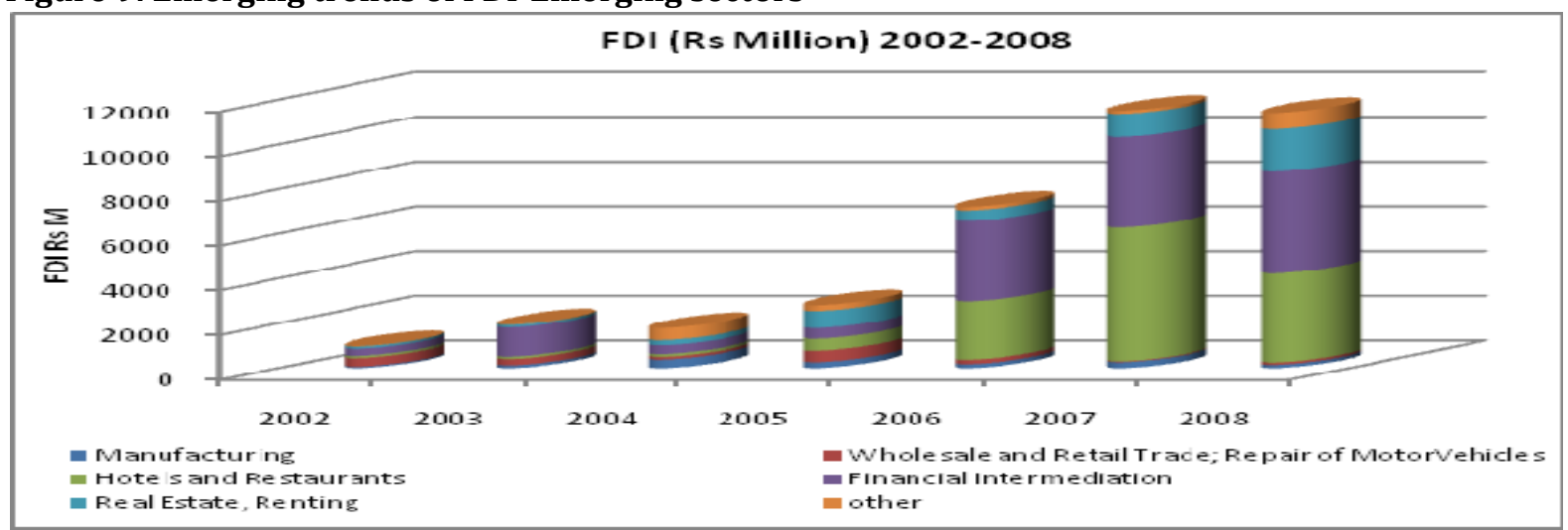

Source: CSO (2002-2009)

Mauritius is not only a tourist destination. It is also classified as the Top 5 countries in the category Small Island Developing States (SIDS), regrouping 29 other countries, which is in line with expectations (UNCTAD FDI Attraction Index, 2011). It is observed that on the African continent, total FDI inflows (Figure 6) has declined in 2011 whereas inflows to Sub-Saharan Africa have improved from USD 30 billion in 2010 to USD 37 billion and that inflows to Mauritius amounted to USD 273 million with outflows of USD 89 million in 2011 (World Investment Report, 2012). Here, it is also important to note that both the public and the private sectors have also play an important role in building five stars hotels on the coast and have been able to integrate people living in the locality to have job opportunities in the manufacturing, tourist and hotel sector in full expansion. The public-private partnerships (PPP) working hands in hands may also account for this sudden economic development in Mauritius. However, after a recent lobbying in the tourism sector the EPZ sector (Table 6 and Table 7 supra) and the textile industry still remains an engine of growth and development in Mauritius (Table 7) though the Mauritian textiles 
and apparel industry faces serious obstacles because of global competitiveness. Minister Rajesh Jeetah ${ }^{4}$ rightly pointed out that: 'The EPZ sector, as one of the major pillars of the economy, has been going through a difficult period during these last three years. It registered negative growth rates of $6 \%, 6 \%$ and $6.8 \%$ respectively in 2002, 2003 and 2004. This year too, the EPZ is expected to register a negative growth of $8 \%$. The situation is therefore not rosy at all'.

Table 8: FDI in EPZ Sector (1991-2000)

\begin{tabular}{llllll}
\hline & UNIT & 1991 & 1998 & 1999 & $\mathbf{2 0 0 0}$ \\
\hline FDI IN MAURITIUS EPZ & RS MILLION & 130 & 27 & 300 & 8 \\
\hline
\end{tabular}

Source: Jeetah\&Coughling P., SADC Study of Textile and Clothing Industry, Mauritius Country Report, 2001

However, there is no doubt that FDI has contributed significantly in the EPZ sector (Figure 10). According to UNCTAD (2007): 'The volume of FDI that flows to Africa is not very low as a share of total global FDI flows or even as a share of FDI flows to developing countries, but also the share is on a steady downward trend for three decades. Africa accounts for just 2 to $3 \%$ of global flows, down from a peak of $6 \%$ in the mid-1970s, and less than $9 \%$ of developing country flows compared to an earlier peak of $28 \%$ in 1976 (UNCTAD 2005). In 2006, FDI inflow to Africa rose by $20 \%$ to USD 36 billion, twice their 2004 level. Following substantial increases in commodity prices, many TNCs, particularly those from developed countries already operating in the region, significantly expanded their activities in oil, gas and mining industries'. Additional funds came from China and India to promote the tourism sector as well, a factor which is not to be neglected. According to the US International Trade Commission, Mauritius exports have increased by $12.6 \%$ from 140 million to 150 million only during the period 2002-2003. According to the Central Statistics Office (CSO), the economy of Mauritius has recorded an average GDP growth of 5\% over the last 20 years (Figure 7), a good indicator of Mauritian excellent trade performance, and once more FDI accounts for this. According to CSO figures, GDP grew by 4.2\% in 2010 which compares favourably with the $3.1 \%$ growth attained in 2009. Exclusive of sugar, the rate works out to $4.2 \%$ compared to $2.9 \%$ in 2009; GDP grew by 4.2\% in 2010 which compares favourably with the $3.1 \%$ growth attained in 2009 . Exclusive of sugar, the rate works out to $4.2 \%$ compared to $2.9 \%$ in 2009.Furthermore, facilities and opportunities are provided to encourage foreign investors to 'stay' in Mauritius. The Board of Investment (BOI) in collaboration with the Immigration Office and the Occupation Permit Unit issue permit for investors who can have a turnover exceeding 3 million rupees, to registered self employed provided he/she has an annual income exceeding 60,000 rupees; registered professionals shall be remunerated at Rs30, 000 or more, issue of residence permit to the registered retired non-citizen provided his/her annual transfer is of at least 40,000 US dollars.

b. Advantage of its strategic position to enhance trade: Mauritius wished to take advantage of its excellent strategic position in the Indian Ocean, a stepping-stone for Asian markets to penetrate the African continent by relying on its various regional economic partnership agreements. It is in the spirit and policy of the government to develop Mauritius as a service hub for the region in order to better position it as a Centre for Capacity Building by supporting the operators of the Regional Multidisciplinary Centre for Excellence and the IMFs' African Regional Technical Assistance Centres provided the region is free from terrorism and piracy. According to the Readers of Condé Nest Traveller Magazine 2008, Mauritius is ranked $19^{\text {th }}$ among the best of Best Top 100 World Destination. Unlike many countries, Mauritius is gifted with natural reservoirs (Mare aux Vacoas, Mare-Longue, La Nicolière), natural indigenous forests (Macabé, Black River Gorges, Nature Park, Pétrin) and mountains (Moka Range, Piton du Milieu, Montagne Lion, TroisMamelles), coastal reefs, unspoiled lagoons, dormant volcanoes (Trou aux Cerfs, Trou Kanaka) and unlimited beaches which are overcrowded with tourists and roamers on week-ends, and which have the merit to be protected. Rainfall is abundant and the sun shines all the year round. The tourism sector, as explained, is contributing to $8 \%$ of the local GDP. Various mechanisms are set up to scan local, domestic, regional and global markets to identify opportunities for the development of specific competitive sectors and products. L'Observatoire de l'Industrie will provide for economic intelligence and information dissemination to economic operator and policy-making. As an illustration, between the period 2007-2011, the National ICT Strategic Plan under the Competitiveness and Public Sector Efficiency Programme, which aims at sustaining growth and employment, shall be reviewed in order to address the impact of the global recession.

${ }^{4}$ Jeetah R. 2005, Challenges facing the textile and apparel industry, Mauritius, workshop 2005 
c. Importance of institutional and legal framework to enhance trade: Most African countries lack proper institutional and legal framework. There are local policies, which may only enhance trade and business in a country and for the country, but they are often overlooked or neglected. Local entrepreneurs in Africa very often have in-house training but with a view to combat poverty and unemployment it is important that there are regular in-house formal training programs (Figure 10). Indeed, who are these investors who wish to trade in a country where, for example, there is no proper institutional and legal framework to regulate investments at all or very few? Sometimes there is nothing new in these local policies because most of them have been inspired or borrowed elsewhere, because there is no need to invent the wheel once more, and implemented in ours for a wealthier nation. If these polices work elsewhere and have been proved to be efficient why should they not work in ours?

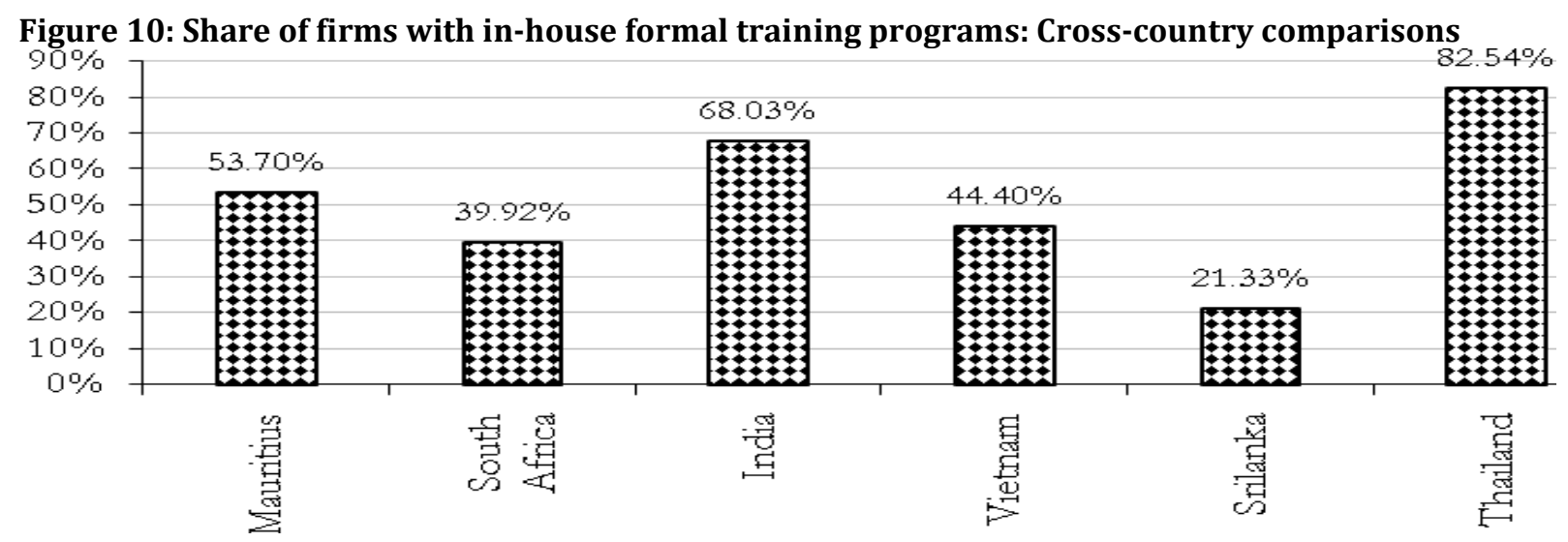

CSo. 2010-2012

Few countries have a road map to investment, trade and various policies. For Mauritius to trade properly and efficiently a very strong institutional and legal framework has been set up with a view to encourage, facilitate and promote investment. The settlement of a legal and institutional framework has been found to be very successful in emerging countries such as China, India and even South Africa. Free and fair election, democracy, wisdom and literacy, good and healthy political stability, healthy investment environment, high rate of employment, independent press, civil liberties and human rights, sustainable environment, productive labour force secure guarantees for foreign investors but over and above all there shall be a reliable institutional and legal framework to avoid mismanagement and popular injustice. New legislations are regularly implemented to improve good governance, ethics management and investment. An arsenal of legislation has been drafted and implemented to safeguard the interest of

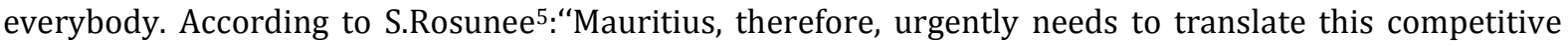
advantage into substantial inflow of foreign investment and skilled job creation. In terms of trade, government policy is to defend acquired markets, as well as to vigorously seek new markets. It seeks to capitalise on all opportunities opened to it (such as through the Africa Growth and Opportunity Act), and has been active in pressing for the opening up of regional and sub-regional groups which it sees as providing opportunities for greater trade and investment. In addition, government, through appropriate legislation, has improved Mauritius's reputation for homeland security an institutional fairness among potential investors".

Termed as enabling bodies, these bodies (Board of Investment, Registrar of Companies, Bank of Mauritius) are operating night and day so that Mauritius; while taking benefits of all its qualities such as beaches, tourism, villas, strategic position in the Indian Ocean; becomes another 'tiger' in the Indian Ocean. However, all Mauritians must work hand in hand to fulfil this achievement because solidarity in what the government is open to avoid unnecessary strikes. The slogan of the government soon became 'Unity in its Diversity'. And all citizens of this country have understood the message. Irrespective whether it is trade or not and for investors to be more secured there is not even one field where there is no legal and institutional framework. In addition, there are very attractive policies to encourage investors in the country. Indeed, the Mauritian Government has introduced new policies with effect from $1^{\text {st }}$ October 2006 to attract foreign investors (in certain circumstances they can even acquire property but for business purposes only) and eventually encourage trade and business in the country. Foreign company are also

${ }^{5}$ Rosunee S. 1990, The Mauritian textile and clothing industry: facing t5he challenges associated with globalization, infd.org/events/wfsids/virtual/papers. 
encouraged to apply for acquisition of immoveable property and they can do so by registering with the Board of Investment (BOI) as an investor. Now an interesting issue is whether intellectual property may contribute to the economy of both developing and developed countries? Industries are more and more dependent on patent protection (computer, pharmaceutical products, aerospace, and semiconductor industries) and copyright (software, data processing, motion pictures, and publishing recording industries). In the USA, industries in the private sector that rely on intellectual property accounted for $40 \%$ of the total growth and are a source of job creation (18 million workers rely on intellectual property in the USA). In 2009, US receipts from cross-border trade in royalties and license fees (patent, trademark, copyright and other intangible rights) totalled 92 billion dollars, an increase of $9 \%$ as from 2007.

If trade encourages investment it may also encourages passing off, counterfeiting, piracy, theft and even un manqué à gagner for local artists. Foreign products are invading local markets and trade could be out of control. The Mauritian Government reacted promptly and several legislations (Copyright Act 1977, Trade Mark Act, Business and Trade Names (Prohibition) Act 1988) have been promulgated. At international level, Mauritius is a member of several organisation namely the World Trade Organisation, TRIPS/OMPI and has ratified the Berne Convention, the Universal Copyright Convention, the Nice Convention 1957 (marques), Locarno Convention 1968 (desseins et modèles) and the Strasbourg Convention (brevets) to protect intellectual property rights. To fight against infringement to intellectual property rights on several and different products (logos, designs and models, patents and trademarks), the Ministry of International Trade with the assistance of other institutions (Mauritius Society of authors, Industrial Property Office) assure policy responsibility for intellectual property rights in the country. Mauritius is ranked 39th out of the 115 countries in the Intellectual Property Rights Index 2008.

d. SMEs in small economies: Indeed, various legislations have been promulgated to promote trade in the informal sector (Fair Trade Act, Business and Trade Names (Prohibition) Act 1988, The Business Registration Act 2007, The Consumer Protection (Price and Supplies Control) Act, Investment Promotion Act 2000, Small Enterprises and Handicraft Development Authority Act 2005 just to name a few), a sector which is properly managed by various institutions (Development Bank of Mauritius-DBM, State Bank of Mauritius-SBM, Small and Medium Industries Development Organisation, Small Enterprises and Handicraft Development Authority), which are ready to give financial (in contrast to other banks which are reluctant to lend money because entrepreneurs are undercapitalised and are viewed as credit risks the Development Bank of Mauritius (DBM) and State Bank of Mauritius (SBM) are two banks which are more than ready to lend money with low interest in order to encourage young entrepreneurs to start business promptly) and material/managerial (SMIDO, Export Processing Zone Development Authority encourages productivity, National Productivity and Competitiveness Council) support in a well planified and diversified economy. Young entrepreneurs usually face the same obstacle everywhere: how to raise funds and capital to run their business in Mauritius. In Mauritius, SMEs are contributing to the GDP and unemployment.

In order for SMEs to flourish in the informal sector there must be a strong legal framework. The Mauritian legislature has promulgated The Industrial Expansion Act 1993 and the Small and Medium Industries Development Organisation (SMIDO) is also made statutory ${ }^{6}$. The Small Enterprises and Handicraft Development Authority Act (SEHDA 2005) came into operation. However, new pieces of legislations have also been promulgated to encourage entrepreneurship in Mauritius namely The Business and Trade Names (Prohibition) Act 1988, The Business Registration Act 2002 where a firm includes an unincorporated body consisting of one or more individuals, or of one or more corporations, having constituted a partnership with a view to carrying business; The Bills of Exchange Act 1914 facilitates negotiations; The Income Tax Act 2005 defines, inter alia, business 7 , relief for double taxation and nonresident who trades in Mauritius; The Borrower Protection Act 2007, The Companies Act 2001, The Consumer Protection (Price and Supplies Control) Act, The Cooperative Societies Act 1976, The Investment Promotion Act 2000, The Cooperatives Act 2005 just to name a few. With such a legal framework for entrepreneurship, local SMEs in Mauritius have been mushrooming occupying $39 \%$ of the share of all employment contributing to 10-22.5 \% of the GDP. According to the National Physical Development Plan, SMEs are contributing to $86 \%$ in the sector employment, $75 \%$ in construction, $67 \%$ in community and personal services, $65 \%$ in wholesale and retail, $13 \%$ in direct exports and around $50 \%$ in transport,

\footnotetext{
${ }^{6}$ The SMIDO Act 1993 was repealed by Act No. 20 of 2005.

${ }^{7}$ Section 2 of the Income Tax Act 2005 enacts that business: "includes any trade, profession, vocation or occupation, manufacture or undertaking, or nay other income earning activity, carried ou with a view to profit".
} 
storage and communication. Mauritius is not the only success story. In Thailand, in 2004, textile and garment exports generated 6.4 billion dollars (4 \% of the GDP), according to the Thai Customs Department. Despite African countries rely on the informal sector to survive young entrepreneurs need funds prior to commencement of business but which most African banks are reluctant to give because young entrepreneurs are risky clients and their firms and businesses may collapse unexpectedly.

Institutions, when they are functioning properly and are made statutory, are capable of formulating comprehensive strategies including advice, finance, training, information, management and marketing support that firms eventually need and especially in the industrial sector. In Mauritius, the Small and Medium Industrial Development Organisation (SMIDO) is giving full support to SMEs and the Export Processing Zone Development Authority has improved quality and productivity. All initiatives by the Mauritian government were found to be fruitful investments. With a population of only 1.28 million inhabitants and its $1866 \mathrm{~km}$ square, there are some 2000 registered small and medium enterprises in Mauritius contributing to $10-23 \%$ of the GDP, had a workforce of 208,000 (41\% of the total employment) generating a gross output worth Rs 42 billion (supra). According to a survey of the World Economic Forum's African Competitiveness Report 1998 out of the 20 African economies, Mauritius is ranked 14th by its measure of procedural efficiency while it was only $23^{\text {rd }}$ in the 2006 Doing Business Survey. And there is still room for improvement. There are young entrepreneurs in the country and they must be encouraged to trade within the country and with other countries. The SEHDA Act has established the Small Enterprises and Handicraft Development Agency (SEHDA) which encourages young entrepreneurs to set up their own business and to create jobs especially in the informal sector and they are given loans at low interest under the Empowerment Programme. Its latest figures reveal that there are around 90,000 small enterprises operating in the country of which $32 \%$ are operating in Trade and Commerce, around 16\% in Leather and Garments, 13.2\% in Food and Beverages and around 13\% in Professional and Vocational Occupations. According to SEHDA ${ }^{8}$ which carries out a Survey Census of Economic Activity 2007 for small establishments every 5 years with the latest in 2007 it was revealed that:

'In 2007, the number of small production units (establishments and itinerant units) operating in the Island of Mauritius and Island of Rodrigues was estimated at 91,980, compared to 74,930 in 2002, that is an increase of $23 \%$. The total number of persons engaged in the small units was estimated at 208,800 $(154,470$ males and 54,330 females), around 19\% higher than the figure of 175,790 (132.950 males and 42,840 females) in CEA Survey 2002(2002). The figures include both full-time and part-time workers, a part-time worker being counted as one person engaged. Total value added generated during 2007 by the small units covered was estimated to Rs 42,130 million, $82 \%$ higher than in 2002 when a value added of Rs 23,200 million was estimated. The contribution of the small units covered in the CEA 2007 to the economy worked out to $20 \%$ compared to $18 \%$ in 2002 . Annual value added per unit increased by $48 \%$ to Rs 458,000 in 2007 from Rs 310,000 in 2002'. In the overall there are approximately 2000 registered SMEs actually in Mauritius contributing to $10-23 \%$ of the GDP as explained. As a result, Mauritius obtained the Award for the most improved Investment Climate at the 2009 African Business Awards held by African Business Magazine and Commonwealth Business Council. The Business Facilitation Miscellaneous Provisions Act 2006 has been introduced to facilitate the regulatory environment for the setting up of businesses. However, the main institution is the BOI as it controls most investments in Mauritius (Freeport activity). For example, the Integrated Resort Scheme (IRS) has been introduced to attract non-citizens who wish to purchase luxury villa, penthouse or apartment in Mauritius provided they are ready to invest a minimum of 500,000 US dollars in Mauritius and to contribute to the National Resident Property Tax creating job opportunities to the poor who are down the economic ladder. Similarly, an investor can purchase property for residential purposes provided he holds a permanent residence permit and that he intends to carry any economic activity with a turn over exceeding 3 million rupees and a non-citizen must first obtain a certificate from the Prime Minister's Office in order to acquire shares in a company.

\section{Development in the sector}

${ }^{8}$ http://www.gov.mu/portal/goc/cso/list 1.htm 

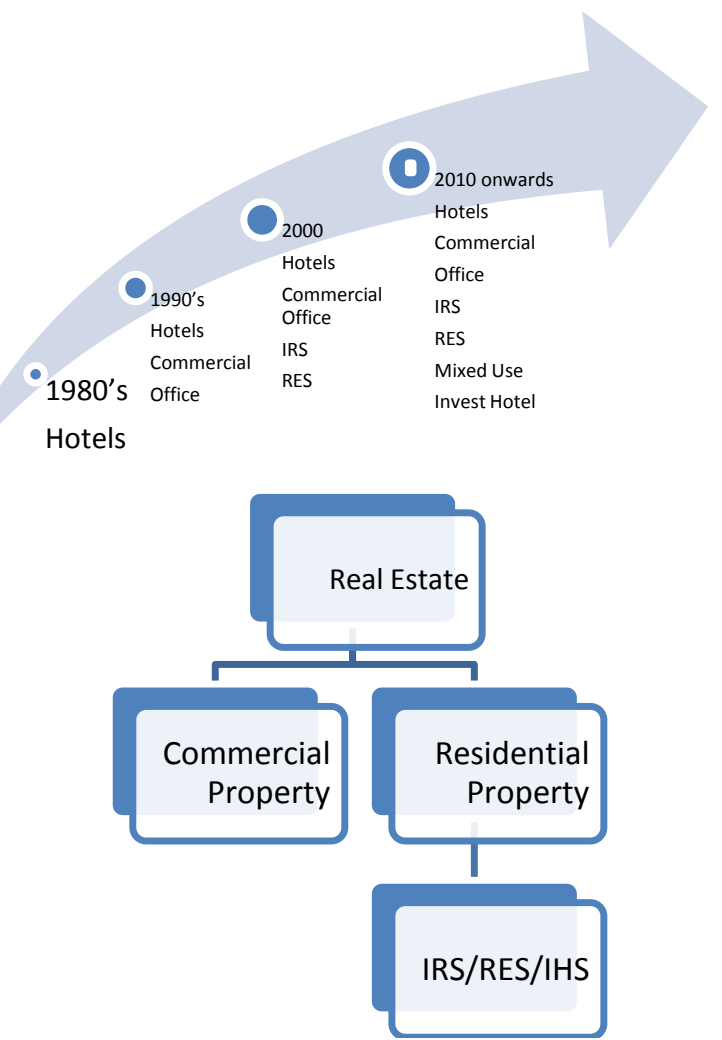

Source: BOI) (Real State. Source: BOI)

Mauritius is also exploiting its 'blue economy' as well. Indeed, its Exclusive Economic Zone (EEZ) covers 1.9 million square kilometres and the seafood sector is an emerging sector in the country with facts and figures which are found to be encouraging: the Mauritian Government has issued 235 licences to foreign fishing vessels (there are 500 fishing vessels for transhipment and bunkering) and some 113,000 tons of fish are caught annually and covers $23 \%$ of the global annual tuna catch originating only in the Indian Ocean (Map 2).

\section{Map 2}

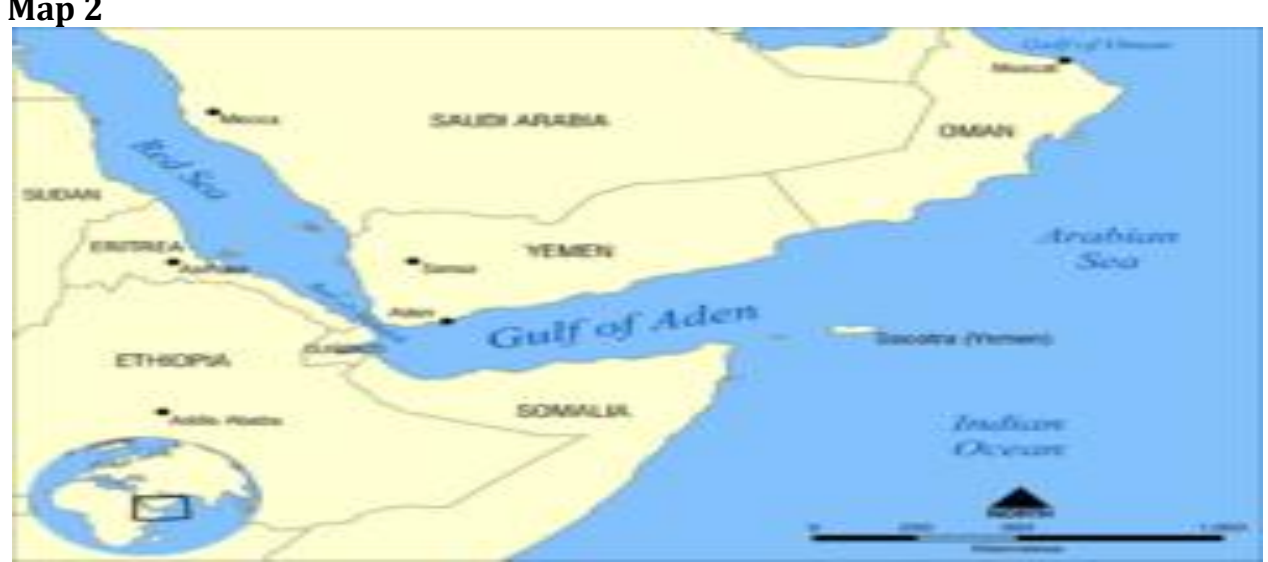

Source: internet

The Seafood hub (aquaculture and fish farming are encouraged after the passing and promulgation of the Aquatic Business Act which is the relevant legal framework for fish farming activities) originated from an initiative of the government and is now contributing to Rs 4 billion accounting for $72 \%$ of the Mauritian exports and representing $18 \%$ of our total exports that is the second largest exports in Mauritius. As an incentive, tax for companies is still low (15\%). However, it is also important to reveal that maritime piracy in the Indian Ocean is now a new scourge. Once more the Mauritian government reacted promptly with a strong collaboration with the government of Seychelles concerning extradition, deportation and sentencing of pirates in this part of the globe. The Mauritian Government will take more initiatives by elaborating much more on a Master Plan (a Rs 2 billion fund will be set up to encourage industrial fishing) 
and its terms of reference shall be the analysis of options for a comprehensive sustainable fisheries development and management plan for both Mauritius and Rodrigues. Entrepreneurs are also encouraged to raise their own private entrepreneurship contributing to job creation and poverty eradication in the country. Another initiative is the L'Institut de la Francophonie et de l'Entrepreneuriat(IFE) which is located on the campus of the University of Mauritius (UoM), lectures are delivered by specialists in this field to promote this area at the UoM and the Mauritian Government is very proactive, once more, to push the SME sector (infra) forward by its latest initiative known as 'SMEase' from the State Bank of Mauritius.

Table 9: Evolution of Small Businesses in Mauritius (1985-2007)

\begin{tabular}{cccc}
\hline Years & Number of firms & Employment generated & \% of Labour force \\
\hline 1985 & 16000 & 47,608 & 22 \\
1992 & 40,497 & 113,274 & 24 \\
2002 & 75,267 & 200,000 & 36 \\
2007 & 92,388 & 211,582 & 37 \\
\hline
\end{tabular}

Source: CSO

In 2007, there were 5 firms employing 747 persons and exporting 549 million rupees worth of goods (clock and watch making). This emerging sector, small businesses, has proved to be efficient against poverty alleviation in Mauritius. Actually, a large number of young entrepreneurs are able to survive with the SMEs they have created and some of them have encountered success in becoming leading entrepreneurs in the country attracting foreign investors in the Tuna industry.

Securities Law to pave an investment environment in Mauritius: Mauritius has experienced a real kick-off in Securities Laws in the year 2007 when the Securities Act 2005 was proclaimed on the $12^{\text {th }}$ September 2007. At the same time, the country was internationally recognised as an active offshore financial sector, which paves the way for foreign investments into Africa and the Asian sub-continent. The Securities Act 2005 has indeed established a legal framework for the regulation of securities markets, depository, clearing and settlement facilities, securities exchange and intermediaries and provides for self-regulatory organisations and regulates the offering and trading of securities. At the 2009 African Business Awards held by African Business Magazine and Commonwealth Business Council Mauritius obtained the Award for the most improved Investment Climate and, according to the World Bank Doing Business Report 2009, Mauritius is ranked first in the African region and $24^{\text {th }}$ out of the 181 countries for ease of doing business encouraging other countries to invest in Mauritius. At the same time foreign investors continue to invest in Mauritius (Table 10)

Table 10: Foreign direct Investment by country of origin for the period 2004-2006 in million rupees

\begin{tabular}{llll}
\hline & $\mathbf{2 0 0 4}$ & $\mathbf{2 0 0 5}$ & $\mathbf{2 0 0 6}$ \\
\hline China & - & 38 & - \\
France & 492 & 427 & 41 \\
Hong Kong & 4 & 7 & 23 \\
India & 150 & 670 & 18 \\
Reunion Island & 5 & 130 & 53 \\
South Africa & 19 & 26 & 6 \\
UK & 143 & 578 & 79 \\
USA & 518 & 75 & 19 \\
\hline
\end{tabular}

Offshore business activity was the term used to define foreign investments in Mauritius but without however having the right to carry out business in Mauritius but this expression is now termed as global business. The Finance (Miscellaneous Provisions) Act 2010 was adopted on the 17th December 2010. It now allows companies holding Category 1 Global Business Licences to conduct businesses in Mauritius. Investments from countries like UK, China, India, South Africa just to name a few suddenly took a new start with the socio-economic development in Mauritius in practically most sectors, emerging or not (Table 11 and Table 12). 


\section{$\%$ of total FDI-2011*}
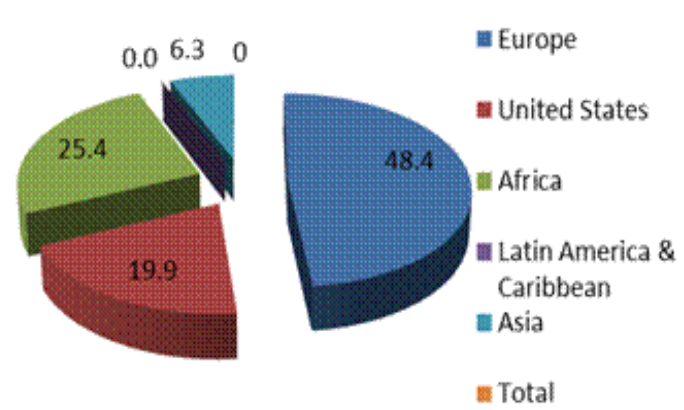

\begin{tabular}{lllll}
\hline Year/Sector & $\mathbf{2 0 0 7}$ & $\mathbf{2 0 0 8}$ & $\mathbf{2 0 0 9}$ & $\mathbf{2 0 1 0}$ \\
\hline Manufacturing & 8.5 & 5.0 & 15.0 & 32.6 \\
Tourism & 100.0 & 46.5 & 57.9 & 16.6 \\
Financial & 127.0 & 157.0 & 42.0 & 68.0 \\
Real Estate & 120.0 & 156.0 & 132.0 & 78.0 \\
Health & ------- & 4.0 & 4.5 & 87.0 \\
Other & 4.5 & 26.0 & 20.0 & 53.0 \\
Total & 360.0 & 394.5 & 270.5 & 335.2 \\
\hline
\end{tabular}

Source: BOI NEWSLETTER, December 2011, Issue No. 37)Source: BoM

In 1988, a new Stock Exchange Act came into operation thus repealing Act 11 of 1987. The Securities (Central Depository, Clearing and Settlement) Act 1996 made provision for the establishment and regulation of a central depository, clearing and settlement service in order to facilitate dealings in securities. The Mauritius Offshore Business Activities Act (MOBAA) 1992 and the Financial Services Development Act 2001 were repealed and the Financial Services Act 2007 came into operation. The Financial Services Commission is empowered by the Financial Services Act 2007 to ensure the orderly administration of the financial services and global business activities, grant licences for securities exchanges; for deposit, clearing or settlement of securities transactions; trading securities systems, is responsible for inspecting and monitoring the financial standing and integrity of stock broking companies, ensuring compliances with the Act and ensure the fairness, efficiency and capital markets in Mauritius.

Securities are now construed as shares or stocks in the share capital of a local or a foreign company, other than a collective investment scheme, debentures, debenture stock, loan stock, bonds, convertible bonds or other similar instruments; rights warrants, options or interests in respect of securities mentioned above; treasury bills, loan stock and other instruments creating or acknowledging indebtness and issued by or on behalf or guaranteed by the Government of the Republic of Mauritius or the government of another country, a local authority or public authority, as may be prescribed; shares in, securities of, or rights to participate in, a collective investment scheme, depository receipts in similar instruments; options, futures, forwards and other derivatives whether on securities or commodities; any other transferable securities, interests or assets as may be approved by the Financial Services Commission; or any such instruments as may be prescribed. The provisions of the Securities Act govern the Stock Exchange of Mauritius. It is also an affiliation to the African Stock Exchange Association, FédérationInternationale des Bourses de Valeursand World Federation of Exchange. Apart its regulatory functions and supervision of the market operations, the Stock Exchange of Mauritius is responsible for listing and monitoring trade data and to detect abnormal trading activity. It operates markets such as the Development and Enterprise Market (DEM) on which securities of listed companies are traded. The DEM is open to foreign investors with more than 43 companies representing a market capitalisation of about Rs 31 billion. Table 1.11 reveals market capitalisation by sector in 2005.

The Financial Services Commission (FSC), a member of the International Organisation of Securities Commissions and of the Committee of Insurance, Securities and Non Bank Financial Authorities, is a financial institution and it emanates from the Financial Services Act 2007. By issuing licences for securities exchanges and ensuring that the criteria imposed are fully satisfied the FSC ensures the orderly administration of the financial services and global business activities and ensures the fairness, efficiency and transparency of financial and capital markets in Mauritius. Another important institution is the Central Depository and Settlement Co. Ltd, which is empowered by the Central Depository and Settlement Act 1996, to establish a clearing and Settlement Advisory Committee to review and make recommendations concerning system designs, operational procedures and problems and transferring the ownership of securities.

Table 12: Market capitalisation in rupees by sector (2005) 


\begin{tabular}{ll}
\hline Sector & \% \\
\hline Banks and insurance & 35 \\
Leisure and hotels & 22 \\
Investments & 15 \\
Commerce & 15 \\
Sugar & 8 \\
Industry & 5 \\
Transport & 3 \\
\hline
\end{tabular}

Source: The Stock Exchange of Mauritius Ltd. Annual Report 2005

Expansion in Mauritian trade services: Sugar is no more one of the pillars of the economy of the country. Recently, it has experienced a drastic cut of $36 \%$ in price obtained for its sugar with the expiry of the Sugar Protocol under the Lomé Convention. According to Rosunee ${ }^{9}$ both the African Growth and Opportunities Act (AGOA) and the Trade and Investment Framework Agreement (TIFA) were ratified at a ripe time but the AGOA was not so beneficial to most African countries because: 'One of the objectives of the AGOA is to boost investment in textile manufacturing as after September 30, 2005 (following one-year extension), AGOA benefits will only be available to garments made up from materials made in the region or in North America. Hence, textile and garment manufacturers need to adapt their supply chain very fast to remain competitive, especially after elimination of quotas'. The TIFA is a bilateral cooperation agreement, which had been signed in 2006 with the US with a view to strengthening and expanding trade ties between the two countries. Well aware that there will be un manqué à gagner for the economy of the country the government reacted promptly to face new challenges with the development of SMEs (voiliers, belts, handbags, hats, fashion accessories) in regional trade was perceived as a good option. The tourism (this sector is contribution to 7.1\%/ 8\% to the GDP with more than 900,000 visitors in 2010 though the country was affected with international financial crisis and diseases such as Chikunguya) and the textile sectors (the textile sector is contributing to $6.5 \%$ to GDP, accounts for almost $11 \%$ of total employment with a share of $52 \%$ of domestic exports) are bringing revenues as well to the country and should not be overlooked (Table 13 and Table 14). Once more, FDI from South Africa, India, UK and China gave a new boost to these emerging sectors.

Table 13: Foreign Direct Investment by sector for 2004-2006 in rupees (millions)

\begin{tabular}{lccc}
\hline Sector & $\mathbf{2 0 0 4}$ & $\mathbf{2 0 0 5}$ & $\mathbf{2 0 0 6}$ \\
\hline Export Processing Zone & 248 & 106 & 11 \\
Tourism & 121 & 425 & 557 \\
Banking & 310 & 454 & - \\
\hline
\end{tabular}

Source: Bank of Mauritius Report (2007)

The Mauritian government found that for investors and tourists to invest and/or to stay in Mauritius security must be a priority. The local authority is laying much emphasis on investments prospects (big game fishing, dolphin watching, business tourism, beauty treatment, plastic surgery, construction of five stars hotels) and which shall be fruitful in the short run. To manage the tourism sector and to maintain sustainable development, licences and work permit are made compulsory in Mauritius. Legislations (Beach Authority Act, Dangerous Drugs Act 2000, Pas Géométriques Act) have been promulgated to punish violators (illegal big game fishing, overexploitation of catamaran without a licence, harassment of tourists on the beach, building near the beach and where nobody has no access to walk on the beach) of the tourism industry. The Police Force now includes a special department for the Police de Plageand a Drugs Department to combat illegal drug trafficking which transit through Mauritius.

\section{EXPORT ORIENTED ENTERPRISES}

${ }^{9}$ Rosunee S. 1990, The Mauritian textile and clothing industry: facing t5he challenges associated with globalization, infd.org/events/wfsids/virtual/papers 


\begin{tabular}{lllllll} 
& Unit & 2007 & 2008 & 2009 & 2010 & 2011 \\
Value added at current basic prices & RsBn & 17.8 & 17.8 & 17.4 & 17.3 & 19.1 \\
Value added/GDP & $\%$ & 8.3 & 7.3 & 6.9 & 6.5 & 6.6 \\
No. of enterprises & No. & 404 & 412 & 413 & 372 & 360 \\
Employment & No. & 67,314 & 62,276 & 58,566 & 55,828 & 55,740 \\
Investment & RsBn & 4.5 & 2.2 & 1.1 & 0.9 & 1 \\
Exports & RsBn & 37.8 & 35.1 & 36 & 40.1 & 41.6 \\
Exports/total exports & $\%$ & 54.3 & 51.6 & 58.3 & 59.1 & 60.1 \\
Imports & RsBn & 21 & 20.2 & 17.3 & 22.7 & 24.2 \\
Imports of raw materials/Imports & $\%$ & 86.8 & 94.3 & 84.9 & 86.5 & 97.7 \\
\hline
\end{tabular}

Table 14: Export Oriented Enterprises

Source: Mauritius Chamber of Commerce and Industry. 2011

It is the policy of the government to accelerate the process of regional integration (especially in the SADCCOMESA region with its half billion people), mobility of workers, cross-border initiatives in key sectors such as food security, climate change, infrastructure, ICT, renewable energy, maritime resources development such that Mauritius is committed to pursue an active international trade policy to fully integrate into the global economy. Development of SMEs offers all these good qualities. With a view to fight against poverty, the Mauritian government, through its corporate social responsibility (CSR) and empowerment programme, has been very supportive and proactive in launching various packages/incentives and plans (National Physical Development plan, National Human Resource Development Plan) to entrepreneurs to begin business as soon as possible provided there is a legal and institutional framework, which soon became the priority of the legislature.

Table 15: External Trade by country in million rupees

\begin{tabular}{llcc}
\hline & & $\mathbf{2 0 0 4}$ & $\mathbf{2 0 0 5}$ \\
\hline Exports & & & \\
& Europe & 35,240 & 38,333 \\
& Asia & 2276 & 7496 \\
& Africa & 6473 & 7195 \\
& America & 8048 & 5990 \\
& & & \\
& Europe & 21865 & 30270 \\
& Asia & 35684 & 44347 \\
& Africa & 11821 & 11292 \\
& America & 3399 & 3807 \\
\hline
\end{tabular}

Source: The Mauritius Chamber of Commerce and Industry (2006)

With its constant, continuous and continuous lobbying, the Mauritian Government is attracting new countries for its export. Mauritian total exports are penetrating the European Union (67\%) and, soon, Mauritius will enjoy the advantages of Third Country Fabric until 2015 but export in the SADC region is paradoxally low: a very poor $0.007 \%$ goes to the COMESA countries, $0.002 \%$ to the SADC members and only 5.89\% to the ACP countries (Table 15). Under The Comprehensive Economic Cooperation and Partnership Agreement, Mauritius is now in a position to export to India 3 million pieces of textile and garments products on a duty-free basis. There is a bilateral trade agreement with Pakistan, which has agreed to offer preferential access to its market (26 garments products are enjoying duty free access). 


\begin{tabular}{lcc}
\hline Exports & & \\
ACP & 4860 & 5488 \\
COMESA & 6623 & 4287 \\
SADC & 1551 & 1440 \\
Imports & & \\
ACP & 11366 & 10570 \\
COMESA & 2350 & 2196 \\
SADC & 9706 & 9400 \\
\hline
\end{tabular}

Source: The Mauritius Chamber of Commerce and Industry (2006)

Products and innovations are one thing but penetrating foreign markets is another thing. Mauritius is a member of most Regional Economic Partnership Agreements (REPA) such as IOC, SADC, COMESA, EU just to name a few in order to extract all benefits and privileges (supra). With the REPA products from Mauritius are exempt from taxes for example with preferential access to EU, COMESA and SADC markets. The seafood industry is generating around Rs 4 billion to the country (supra) and there is still improvement to be made to this emerging sector. Mauritius is expanding its exports to potential markets such as China and Japan. Asiatics are very fond of seafood (tuna, seacocumber) and there have been major and important development for trade in the seafood sector but since overexploitation (unfortunately too many licenses have been issued and granted to EU companies and Japan Tuna Fisheries Cooperation Associations for fishing activities in the Indian Ocean) may jeopardized this sector. Consequently, shrimps, crayfish, crabs, eels, tuna fish are exploited and exported subject however to fish farming in unpolluted marine farms around the country. According to some latest incentives the Mauritian Government, which aims to increase its quality and quantity, there have been many developments in the seafood sector and no other sector has been able to have such financial support. Incentives and support are simple and unpretentious but their efficiency is not put into question: construction of cold warehouses, platform for transhipment, patrols to overcome illegal fishing in the Indian Ocean, fast track cargo release through the electronic clearance of goods just to name a few

Regional Integration: Mauritius is a member of most regional economic blocks (supra) in the region but being a member of a number of regional economic blocks (see map below) has not contributed for its economic success. Language barriers, competition without any single harmonisation for a common currency account for this.

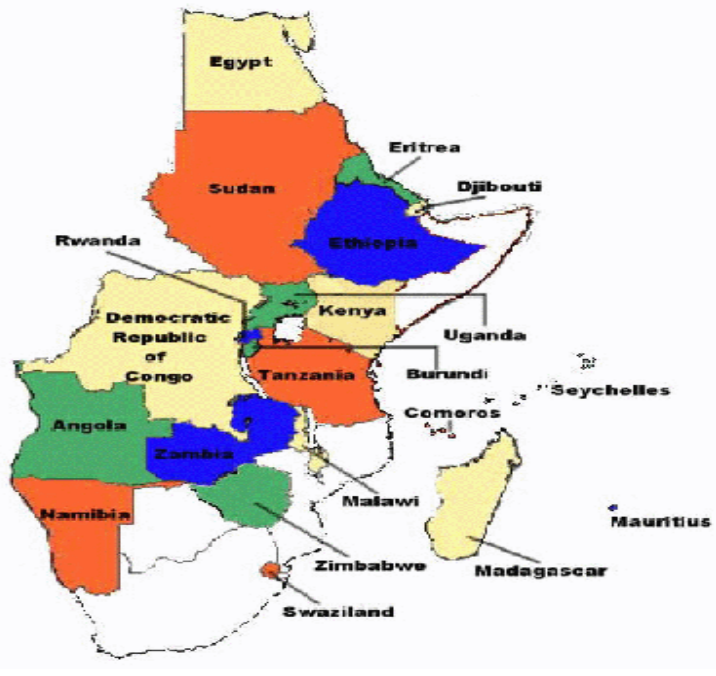

COMESA (source: website)

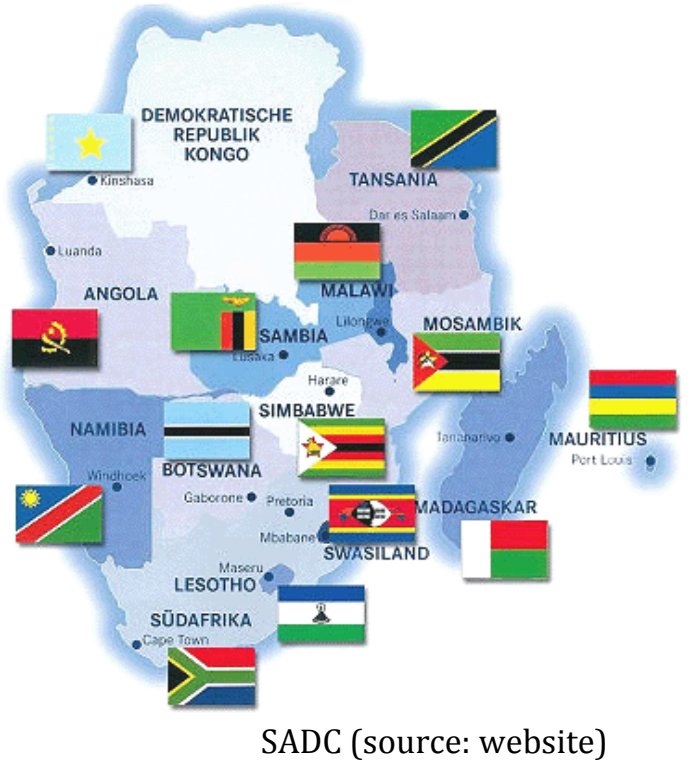

Alternatives to regional integration: Are there alternatives to regional integration? Is there evidence to prove that the regional integration was successful or not to Mauritius and its economy. Except to some few exceptions (South Africa, Mauritius) most members of the regional blocks (COMESA, SADC) have not been able to export properly. Why? At domestic level there is still a lack of infrastructures, continuous devaluation of the local currency as wellon the African continent, very weak institutions and legal framework, political instability in some countries of the African continent and members of the REPAs, international crisis, lack of harmonisations in the regional economic partnership, inability to achieve a 
common currency, language barrier just to name a few may account for regional disintegration (infra). Even social security in Africa is weak (Table17). Again and once more Rosunee ${ }^{10}$ pointed out clearly in his research that: 'In the regional level, Mauritius has done well with the share of manufacturing value added (MVA) in the GDP being about 19\% while for most African countries MVA remains below the minimum $16 \%$ required on an ongoing basis for sustainable development. Moreover, the African continent has seen its GDP per capita fall between 1990 and 2000, from USD 755 to USD 673'.

Table 17: Social security in the SADC

\begin{tabular}{ll}
\hline SADC member & Social Security \\
\hline Tanzania & $5.98 \%$ \\
Madagascar & $14.9 \%$ \\
Mauritius & $85.6 \%$ \\
Zambia & $7 \%$ \\
\hline
\end{tabular}

Source: SADC (2011)

Most countries of the sub-Saharan region are still exporting raw materials to survive in a global world where competition is fierce. Developing countries, which are exporting electronic and electric devices and appliances, shall soon be more competitive than the USA, France or Britain. China (Greater Mekong Sub region, ASEAN Free Trade Area) and India are now potential leaders to challenge any competitor in the world actually. Their products are invading most markets in the world. The Asiatic know-how, trade liberalization, cooperation with most countries of the world, successful regional integration with all types of facilities (preferential trade agreements, free trade areas, customs unions, common markets, economic and monetary unions) and implementation of national policies are accountable for the Asian success. By invading the African market with products and goods China and India will eventually use Mauritius a stepping stone to conquer Africa

Regional integration or regional disintegration? The aims and objectives of Economic Partnership Agreements were to align bilateral arrangement between ACP countries and The European Union. Though member States enjoy duty free access to the SADC members and though Mauritius enjoys tarifffree trade with other eight African countries in the Common Market for Eastern and southern Africa (COMESA) trade in terms of import-export is still negligible in all its sense. To the exception of the Republic of South Africa, in terms of trade, import and export regional integration has never been beneficial to any country and even to Mauritius, though it has contributed a very influential role in the region.

Table 18: Export in the SADC region (\%)

\begin{tabular}{lllccc}
\hline Country & $\mathbf{1 9 8 0}$ & $\mathbf{1 9 8 5}$ & $\mathbf{1 9 9 0}$ & $\mathbf{1 9 9 5}$ & $\mathbf{1 9 9 9 - 2 0 0 0}$ \\
\hline Angola & 0.2 & 0 & 0 & 0 & 0.9 \\
DRC & 0.4 & 0.1 & 0.1 & 2.7 & 0.1 \\
Malawi & 11.1 & 6.1 & 0.5 & 1.9 & 2.3 \\
Mauritius & 2.2 & 0.1 & 1.4 & 0.6 & 0.6 \\
Mozambique & 1.8 & 0.1 & 0.1 & 1.4 & 0 \\
South Africa & 64.2 & 50.5 & 56.0 & 76.5 & 77.8 \\
Seychelles & 0.2 & 0 & 0 & 0 & 0.1 \\
Tanzania & 9.6 & 0.1 & 0.2 & 0.3 & 1.3 \\
Zambia & 4.4 & 4.1 & 1.0 & 1.3 & 2.0 \\
Zimbabwe & 6.0 & 38.9 & 40.7 & 15.4 & 14,9 \\
\hline
\end{tabular}

Source: World Trade Analyzer Data (1999)

In Mauritius, there is only one main harbour (Port-Louis, the capital of the country). It caters for harbour services and facilities, container handling, transhipment and manipulation of bulk commodities. The Freeport Unit of Board of Investment and the Mauritius Cargo community Services Ltd are two additional institutions, which promote and facilitate business in the Mauritius Freeport and cargo information.

Table 19: Port Trade 2004

\footnotetext{
${ }^{10}$ Rosunee S. 1990, The Mauritian textile and clothing industry: facing t5he challenges associated with globalization, infd.org/events/wfsids/virtual/papers
} 


\begin{tabular}{lc}
\hline Traffic & Million tons \\
\hline Total traffic & 5.85 \\
Bulk traffic & 3.22 \\
Total container traffic & 244 \\
\hline
\end{tabular}

Source: Central Statistics Office -2005

For improvement in trade in import and export, there shall be reliable infrastructures and modern telecommunications. The Romans know it well and they had developed a network of roads and infrastructure from Rome to most remote regions of the old continent. Development in its harbours explains the South African's success in the REPA and accounts for better trade in its exportation. Safe to some few exceptions, in most countries of the world shipping connections are still unexploited or underdeveloped. Containers are loaded manually. Countries of the SADC (South Africa is an exception) are still under exploiting their harbours. The Mauritian Government is encouraging Public Private Partnership (PPP) to promote new infrastructures (airport, roads, bridge, metroléger). According to Nurudeen (2010), private and public investments are closely related; governments should invest in infrastructure if they want to attract private investment and FDI. Language barriers, lack of harmonisation in terms of legislations, customs union, common market, economic union and a common currency just like the Euros in the Economic Union are major obstacles members of the regional Economic Partnership Agreement (EPA) are facing today. The Cotonou Agreement has come to an end (2007) and it is urgent to look for other trade agreements. A list, whether exhaustive or not, is not important but it shows to what extent the Mauritian Government is ready to extent its relations to other countries in order to achieve regional economic integration and international recognition both for its imports and exports.
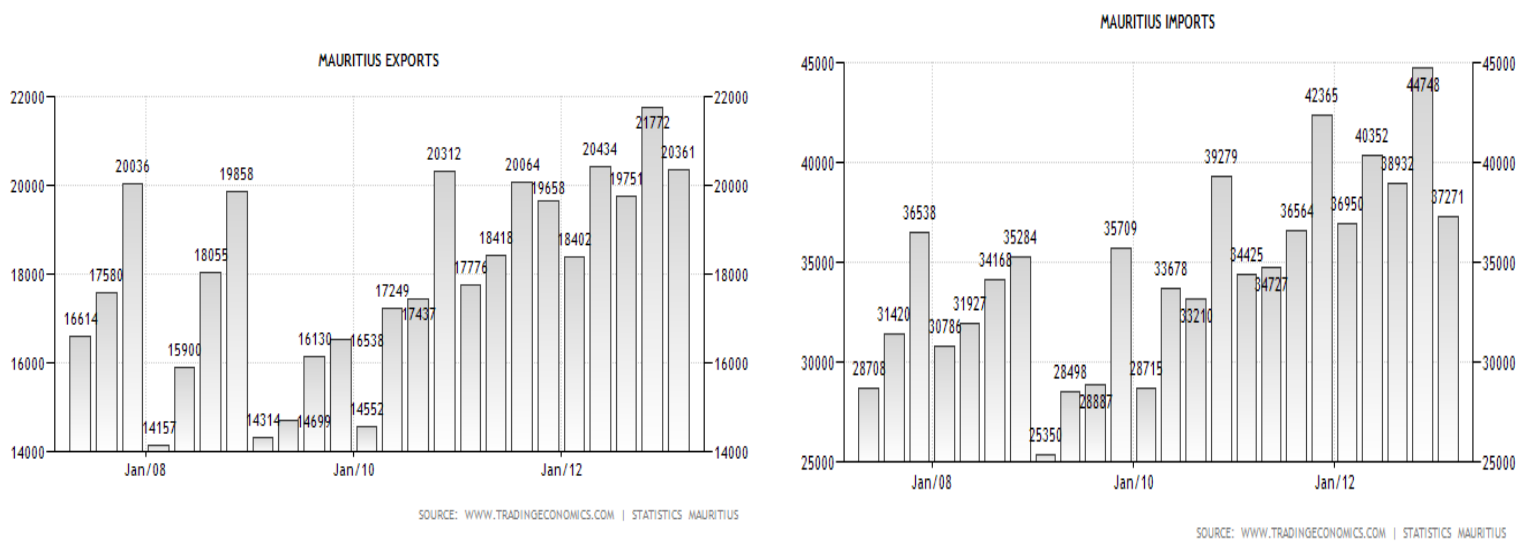

\section{Key factors to enhance trade in the Indian Ocean: the Asian Financial support}

There are some key factors, which may enhance trade in the Indian Ocean and eventually in the subSaharan region. Mauritius took serious challenges in enhancing trade by encouraging the development of small and medium enterprises (supra) and eventually then to conclude bilateral agreements with some Asian countries. China and India are two greatest investors in Mauritius. The Comprehensive Economic Cooperation and Partnership Agreement between Mauritius and India covers areas of trade in services, investment and Economic cooperation. In addition to various types of assistance to Mauritius in agriculture, education and sports, China is financing the Mauritian Government to build airports and other infrastructures. As an illustration of India's financial and economic support to Mauritius India has financed the Cyber City at Ebène. In return, imports from China grew from 10 billion rupees to 13.6 billion rupees from 2006 to 2007 but imports (fish) were around 121.1 billion accounting for $80.9 \%$ of our GDP. Mauritius is also purchasing oil directly from India in order to avoid paying additional taxes. Indian Oil Stations are mushrooming around the island creating jobs and employment and generating income to the country. Therefore, policy of the government is to trade and let others trade in the country as well. They need plots of land but who will lease or sell his/her plot of lands? The Integrated Resort Scheme (IRS) and the Real Estate Scheme (RES) were the answer: the Board of Investment (BOI) (Figure below) will issue an IRS certificate if the board approves the IRS project. A large number of investors have 
IRS certificate and they even benefit from the Morcellement Tax, Registration Duty and Land Transfer Tax.

\section{Investment in IRS/RES units}

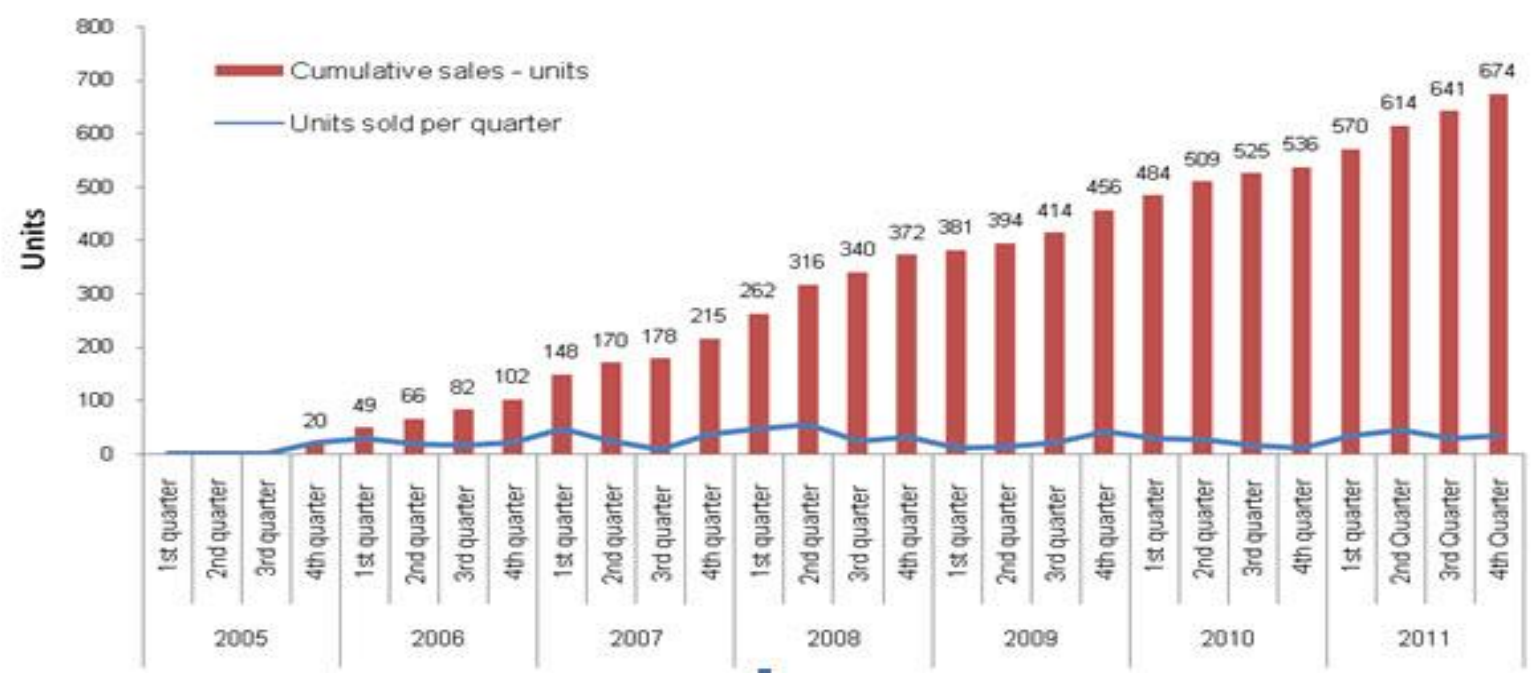

(Source: BOI. Annual Report 2011)

The property industry is contributing to $11.9 \%$ (2009) of the GDP increasing from 10.5\% in 2006 to 11.5 in 2008 and contribution to economic growth is around 0.7. Asian countries want to invest in Africa provided there is a good social and political environment in addition to its economic opportunities. While investing in Mauritius, these Asian countries may also benefit directly and indirectly from agreements Mauritius has signed or ratified (Mauritius has signed the ACP-EU Convention, of the European Free Trade Area, Interim Economic Partnership Agreement, Trade and Investment Framework Agreement, Bilateral Investment Treaty) without being a member of the Regional Economic Partnership Agreements (customs duties for COMESA is zero \% and are very attractive indeed) at all.

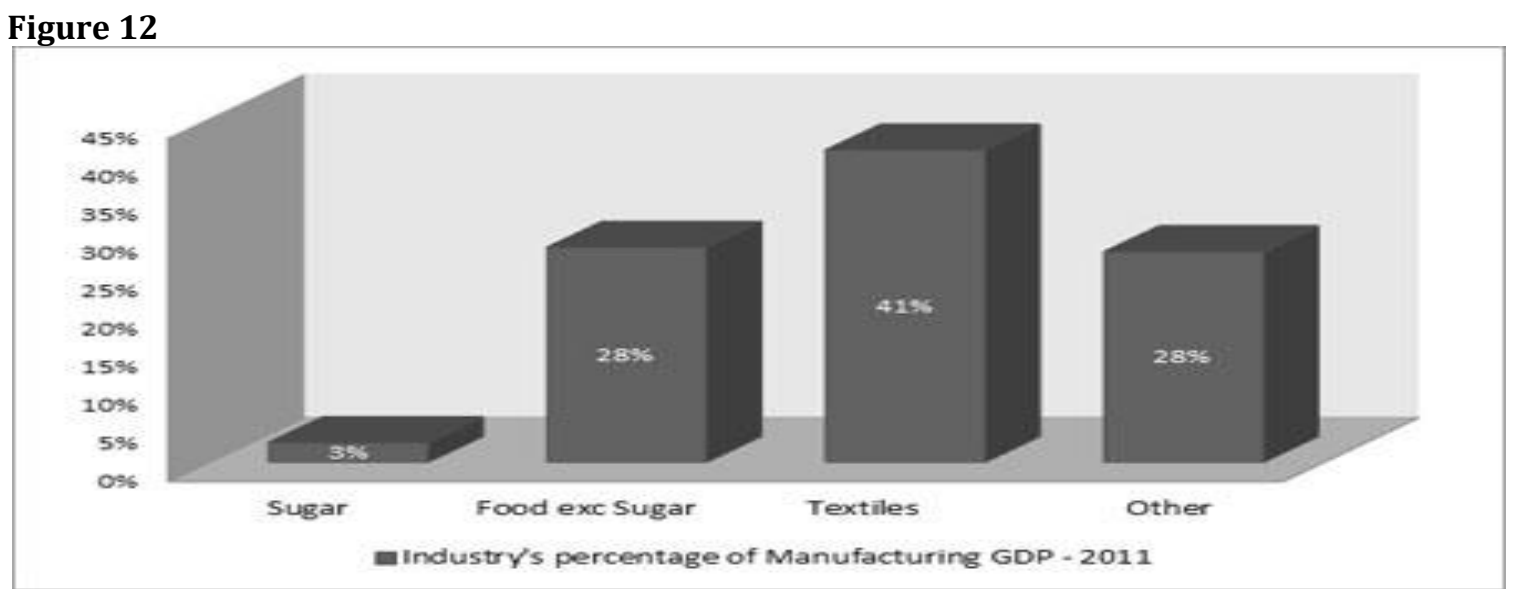

Source: Board of Investment (BOI)

The Tianli Enterprise Group, a Chinese firm, is investing 100 million dollars in Mauritius to promote trade, infrastructural works and a spinning plant in the country (Figure 9). It will also provide headquarters for Chinese business after the establishment of a Trade and Economic Zone. It is estimated at about 530 million dollars and the Tianli enterprise will bring some 20 billion rupees of investment. In return, China will take benefit of the preferential market access Mauritius is enjoying from the African region (COMESA and SADC) and AGOA. It seems that Mauritius is enjoying the China-Africa Cooperation and its funds, which are generated by the China Development Bank. Up to now, it has provided one billion US dollars to develop cooperation with Africa. The China-Africa cooperation which was settled in October 2000 during the Forum on China Africa Cooperation and after the Beijing Summit, which was held in November 2006. Goods and various imports (machines and apparatuses) from China are invading the 
African market and China are exploiting natural resources such as Tuna fish in the Indian Ocean. Furthermore, Chinese goods and products can penetrate the COMESA (with its 380 million inhabitants with intra-trade exceeding US 120 billion dollars while customs duties is zero \%0), SADC with its 230 million inhabitants generating a combined GDP of US 200 billion dollars, the AGOA and even the Indian Ocean Commission (IOC) which was set up in 1982.So, through the sub-Saharan countries there are various gateways for the Chinese markets to penetrate Europe and USA. The African Growth and Opportunity Act (AGOA) allows African countries to export their products to the USA market, duty free and quota free but unfortunately since it was ratified for a short period only it did not provide the best solution for Africa. Since China will not benefit from the AGOA's privileges, Chinese can nevertheless set up companies in Africa, use some materials made in Africa and export to the USA while enjoying all the privileges of free trade provided value added is at least $35 \%$ !

Delocalisation and New Markets: Delocalisation and new markets depend on "lobbying". It rests on regular visits of ministerial delegation to Madagascar and South Africa in order to explain the Mauritian's visions in the region. The Mauritian government is struggling hard to impose an intensive industries and investment in some key sectors (tourism and textiles though competition is high with other neighbouring countries) in the sub-Saharan region coupled with a Regional Development Certificate Scheme (it provides fiscal incentives to Mauritian who wish to invest in the region). Up to now there have been very positive results. Actually, there are some 100 Mauritian companies, which are operating successfully in the region (Table 20). Eventually, the Mauritian lobbying in looking for other emerging sectors such as tourism has been fruitful both in fighting against unemployment and eventually against poverty. It is expected that the African Growth and Opportunity Act (AGOA) will be another additional support capable of strengthening the African economic development.

Table 20: Manufacturing sector in Mauritius Manufacturing Sector

\begin{tabular}{|c|c|c|c|c|c|c|}
\hline & & 2007 & 2008 & 2009 & 2010 & 2011 \\
\hline Sugar & Rsbn & 1.2 & 1.1 & 1.0 & 0.9 & 1.0 \\
\hline Food & Rsbn & 12.2 & 15.9 & 16.0 & 16.6 & 17.8 \\
\hline Textile & Rsbn & 14.7 & 13.9 & 14.2 & 13.6 & 15.0 \\
\hline Other & Rsbn & 13.3 & 16.2 & 16.1 & 16.7 & 18.3 \\
\hline Total manufacturing & Rsbn & 40.2 & 47.1 & 47.3 & 47.8 & 52.0 \\
\hline Sugar/GDP & $\%$ & 0.7 & 0.5 & 0.4 & 0.3 & 0.3 \\
\hline Food/GDP & $\%$ & 5.7 & 6.6 & 6.4 & 6.2 & 6.2 \\
\hline Textile/GDP & $\%$ & 6.8 & 5.7 & 5.6 & 5.2 & 5.2 \\
\hline Other sector/GDP & $\%$ & 6.2 & 6.6 & 6.4 & 6.3 & 6.4 \\
\hline Total manufacturing/GDP & $\%$ & 18.7 & 19.4 & 18.8 & 18.0 & 18.1 \\
\hline \multicolumn{7}{|l|}{ Growth rates } \\
\hline Sugar milling & $\%$ & -13.6 & 3.7 & 15.0 & -4.0 & 1.6 \\
\hline Food & $\%$ & 2.5 & 7.7 & 3.8 & 4.4 & 0.7 \\
\hline Textile & $\%$ & 9.9 & 0.1 & -0.2 & 0.0 & 8.3 \\
\hline Other & $\%$ & -4.4 & 2.3 & 1.5 & 2.1 & 2.5 \\
\hline Total manufacturing & $\%$ & 2.9 & 3.2 & 2.1 & 2.1 & 3.5 \\
\hline Empl. in large establishments & No. & 92261 & 93877 & 82635 & 79819 & 77422 \\
\hline Empl. in man./total empl. in large est & $\%$ & 30.8 & 30.5 & 27.8 & 26.5 & 25.6 \\
\hline
\end{tabular}

Source: Mauritius Chamber of Commerce and Industry (2007-2011)

The number of our Mauritian companies is increasing rapidly while a trade turnover of 20 million rupees has been registered since 1986 only in the COMESA market. By 2000, imports and exports from Mauritius have increased by $1,000 \%$ due to dismantling of tariffs in the COMESA and secondly, Mauritius has been exporting goods and materials to the 21 members of COMESA useful for their needs (wheat flour, chemicals) and wants.

Obstacles to trade in Africa: The Private Sector and trade: Compared to other continents, trade in Africa has been relatively a very slow process. By 2010 there was supposed to be a common external tariff, a common market pact by 2012 and a SADC Central Bank by 2016. Hopelessly so, there has been any development so far. It is not denied that there cannot be trade in Africa unless there are free and fair trade areas, customs unions, harmonization and coordination of policies and a common market. In 
addition to these commitments, African officials shall now look upon additional cooperation with other countries, which have expertise in agriculture, finance, investment, human development and the important contribution of the private sector, which plays a very minor role in most African countries. The private sector (supra) plays an important role in Mauritius. The Joint Economic Council, which represents the private sector in Mauritius, encourages investment promotion, privatisations plans and mobilisation of private capital for infrastructure projects such as transport by land and sea, telecommunications (France Telecom became Mauritius Telecom) and even contribution in the settlement of tertiary intuitions in the country. Some schools even provide education and training in order to equip school leavers for a better quality service in our hotels.

Solutions to stumbling blocks: One major obstacle to intra-Africa trade is lack of infrastructure, nonconvertible currency, and political instability. Most regional blocks in the African region are stumbling blocks. Up to now, not all customs duties, tariffs and/or quotas have been removed properly. A common custom union is inexistent and there has not been complete trade integration, labour market integration, capital integration and a monetary integration like the European Union, which seems to be functioning rather well. Instead in Africa, funds are rare as there are fewer contributors for the European Development Fund and secondly, socio-economic development and political stability are both relatively different from one country to another accounting for an unequal economic and financial development in most countries of the REPAs. Since the regional economic partnership agreements may give very little hope to trade discussions must continue in the Agreement on Subsidies and the Countervailing Measures, which were raised from the CANCUN Agenda and the Doha Development Agenda. There are other factors that may cause regional blocks to be stumbling blocks thus affecting trade in Africa and members of regional blocks such as COMESA and SADC are inter alia:

-Poor domestic legislations on trade. Sometime they may be inexistent or outdated

- Droughts and water scarcity are exciting farmers to kill each other. The African continent (Ethiopia, Namibia) is affected by droughts. Impacts of climate change may change on the economy of a country. Floods ravaged Mozambique in 2000 and 2001 and Connie, a tropical cyclone, visited the eastern region of Africa and hit Mozambique. In case of tsunamis, cyclones or any natural disaster railways and crops will be damages and Africa shall be prepared to them. This growing vulnerability is intimately linked to development and trade patterns: population growth , massive displacement of people from rural to urban areas will create poverty and unemployment, social injustice and short term economic vision are producing vulnerable societies

- Diseases affecting both animals and plants with loss of income

- Water must be stocked in reservoirs either natural or artificial

- The creation of a large number of regional blocks is discriminating other African countries, which are not members to a block or configuration

- Members of the regional blocks are producing the same products (sugar, beer, poultry, fertiliser, cosmetics, steel, tobacco, tea, soap, detergents just to name a few) and are importing the same products. Markets are also saturated with the same products.

- Trade diversion but a country must specialise in what it can do best

- African countries have different labour cost with Mozambique where the monthly salary is \$44 whereas in South Africa, the labour cost is around \$ 284 per month. Mobility of workers and traders are discouraged eventually.

- Members of the SADC block may also be members of the COMESA block and it is hard to harmonise rules and regulations and is consequently rather difficult to create a common dispute settlement body for countries of the African continent

The economical impact on the African regional blocks: According to the South African Reserve Bank, the SADC countries host a small share of the total South African FDI. The main explanations are that there is limited investment in manufacturing (60\% of South Africa investment in the SADC area is greenfield investments or expansion of existing capacity) and secondly South Africa is primarily exploiting the natural resource base of its host countries. For example, Mozambique is the most important recipient of South African investments followed by Zambia, Malawi and Zimbabwe. It is advisable for African countries to reduce their tariff trade and some are doing it more rapidly than others. Reducing tariff trade has proved to be successful to trade. Members (Canada, US and Mexico) of the Northern American Free Trade Agreement (NAFTA) have demonstrated that they are capable of eliminating tariff trade. In addition, there shall be more individual support between members of the same regional bloc. As from 2006, Mauritius has enjoyed a tariff preference of $40 \%$ in garments export to South Africa over non-SADC members. Furthermore, with the aim of attracting investment the European Development Fund has 
donated 13,5 billion for the ACP and the tandem EU-ACP arrangements will reduce tariff barriers reciprocally and progressively. However, there is food for thought: only a very few $6 \%$ of Africa trade with other countries of the continent while $60 \%$ of the total exports are concentrated only on a few products only. The African Growth and Opportunity Act (AGOA) has been more beneficial to the SADC members rather that the SADC itself. Products of the garment (jackets, dresses, skirts, clothes) industry have been invading the US market and again South Africa is leading the way with $69 \%$ of the share, Kenya with $44 \%$, Lesotho with 18.5 and Mauritius is at $12 \%$.

Mauritius: the African Cub-Tiger: Mauritius has tried to jump all obstacles on its way to progress and development at a time where most African countries had to face recessions, international financial crisis, droughts, climate change, political and social instability just to name a few. Mauritius has faced hard times as well. There were drastic cuts in sugar price, the Lomé Convention and its preferential trade agreements came to an end, phasing out of the Multi-Fiber Agreement in 2004 and increase in price of oil and other commodity prices. However, Mauritius stood firm to most international financial crises. If Mauritius wished to be the new "African Cub-Tiger", it has to invest, trade with a series of government policies which are implemented coupled with fruitful lobbying in foreign countries (USA, India, Europe) to attract investors, businessmen and to enhance its tourism sector. Its economic, social and political stability also account for its progress and wealth. In addition, Mauritius has developed adequate market access, a good network for communication facilities, financial infrastructures to encourage and promote foreign investment, development of management skills and a sound macro-economic management, trade policies with foreign countries, adequate production base, development sufficient commercial and marketing skills to enhance trade with other countries and members of regional and international blocks. Mauritius shifted from an agricultural country to a modern country where there are inter and intranet facilities. For African countries to be able to trade prior to commencement in trade and business they might be interested to inspire from Mauritius (however cyclones and brains running away from the country to settle abroad have negative impacts on its economy):

-Development in emerging sectors such as tourism, service-oriented industries and SMEs. For trade to flourish, Mauritius has improved its services (tourism and offshore services). Actually, its service sector occupies 50\% of its GDP and it accounts for 5\% of its total trade. During the period 1990-1999; Mauritius, Botswana and Seychelles have successfully posted saving rate exceeding $25 \%$.

- Opening of its market to 400 million consumers through its membership to various regional blocks it belongs (COMESA, SADC and IOC)

- It is still as a platform between the different continents and tries to bridge Asia to Africa

- Promotion of its business hub and an aggressive lobbying in the tourism sector capable of attracting tourist from Europe, Africa and some islands in the Indian Ocean.

- Bilateral cooperation between Mauritius and some giants such as China, India, France and the USA (AGOA).

- Liberalisation of its air access to most lines of the world through mutual agreement between Air Mauritius and Air France, British Airways just to name a few with the result that the local aviation company has no seat, or very few, to offer on its regular flights around the world and with a turnover of several millions of rupees

- Continuous reforms in different sectors in order to be in line with modern views and ideas

- New and stronger policies, which are launched by the Mauritian government to encourage trade, business and investments in the country. There has been development of an Export Processing Zone (EPZ) for the local and foreign investments

-Major developments in its banking sector. Most banks on the island have registered a net profit of billion of rupees. The Mauritius Commercial Banks have a net profit of 2 billion rupees, an increase of 15,2\%. Banks are important for trade (Singapore, China, Mauritius, and India), financial investment and promotion of offshore companies in the country. In addition, they favour employment and the wealth of a country. China next objective is to conquer the African continent where labour market is good reliable and less expensive. May be China and India are the alternatives for African moves towards success and wealth.

- The three necessities for any business entities are power, water and business friendly environment.

- Mauritius has made remarkable progress in various sectors such as agriculture, manufacturing, services, logistics, and infrastructure just to name a few. Education is of good quality and it enables citizens of Mauritius to trade efficiently with potential investors.

\section{Poverty alleviation and trade}


Diversification of the economy: Again, compared to Africa and other regions of the world, Mauritius has its own specificities: low unemployment rate (5\%), low affected rate of HIV/AIDS, environment is clean and safe, political and social stability, no civil wars, the regime in place is safe and trusty, election is free and fair and there are no lord wars, guerrillas and other freedom fighters just to name a few to plunder the economy of a country. Indeed, unlike many other countries Mauritius is a Welfare State where education, health, dispensary and other facilities are free. But where the money comes from? Most emerging sectors (IRS, tourism and manufacturing) in Mauritius are attracting foreign direct investment giving a good boost to the small economy of Mauritius such that all citizens of this country can share but what is more important is that these sectors have created jobs pushing a little back every year poverty, unemployment rate and hunger. However, the greatest achievement in Mauritius to poverty eradication has been the implementation of Corporate Social Responsibility which is made statutory and its contribution in poverty eradication. The legislation came into force after the 2009 budget whereby companies, monitored by a National CSR Committee CSR projects, are required to use $2 \%$ of their book profits for the implementation of CSR projects such as socio-economic development, health, education and training, leisure and sports, environment and catastrophic interventions and support. Only in 2012, Rs 256 million representing about $63 \%$ of CSR funds have been dedicated to socio-economic development.

Actually, unemployment is low (5\%) and is a good blow against poverty. In addition, improvement of institutional and legal framework to give financial and educational support to local entrepreneurs to raise their own small enterprises, local strategies to improve environment and health against diseases such as HIV/AIDS, various Poverty Alleviation Programmes (Empowerment Programme, Decentralised Cooperation Programme, Trust Fund, Committee on Poverty Association of the President). Hurbungs ${ }^{11}$ (2008) found that: 'A World Bank recent study has estimated 9.7\% less than Rs 5000 per month. Poverty in Mauritius is localised rather than widespread. Based on relative development index by Central Statistics Office, a list of 53 deprived areas has been established. Adopting a targeted approach, the Trust Fund has indentified 229 pockets of poverty with an average of 50 households. The total number of households counted, as absolute poor is around 8000 and a population of 30,000 members'. The economy of a country must be well diversified and it should not be focused in one sector only. As a result Mauritius has succeeded with a well-planned and diversified economy including agriculture and agro-industry (sugar, tea, tobacco, coffee), construction, tourism, financial services and the ICT-BPO sector just to name a few.

Figure 13

\section{Professionals employed in the ICT-BPO sector}

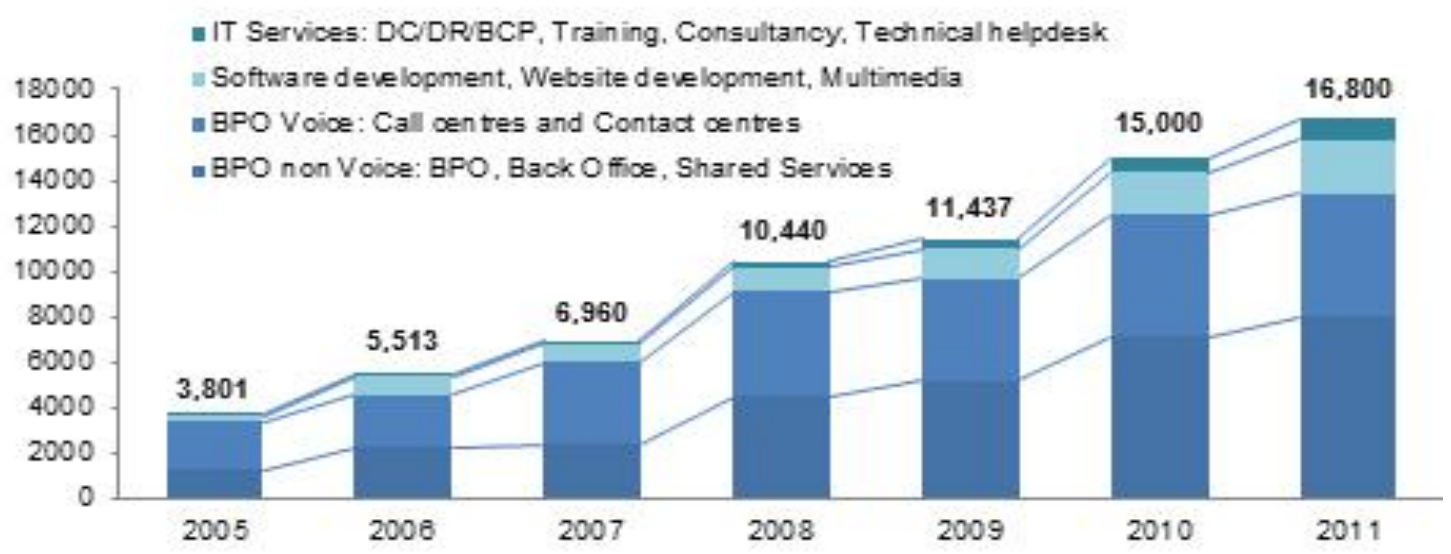

(Source: BOI NEWSLETTER, December 2011, Issue No. 37)

Had Mauritian been focusing on its agricultural sector only may be there could have been any economic boom in the country. Prior to diversification of the economy, it is important to note that Mauritius intended a reliable, safe, fruitful and stable political and economic environment to attract foreign investors and to trade with other countries and members of the region. This policy of long-tem

\footnotetext{
${ }^{11}$ Hurbungs S. 2008, An evaluation of the different poverty alleviation programmes in Mauritius, Caslon Printing Ltd, Mauritius
} 
development was rightly pointed out by Rosunee ${ }^{12:}$ 'With trade liberalisation, the Mauritius textile and clothing industry is now faced with a number of short and medium-term challenges, on both the internal and external fronts. These relate mainly to elimination of trade preferences, exchange rate fluctuations, relatively slow pace of restructuration and diversification, increased competition from low-cost manufacturers, rising costs of air and sea freight, and low penetration of new markets'. In Mauritius, to promote sustainable development especially neither the private sector nor NGOs are left on the bench. The private sector is not neglected and bodies such as the Joint Economic Council, Mauritius Chamber of commerce and Industry, American Chamber of Commerce, Chinese Chamber of Commerce, Indian Traders' Association, Mauritius Employers Federation and the Tamil Chamber of Commerce and Professionals which contribute to the economy of the country as well. As Padachi ${ }^{13}$ rightly pointed out in his research on SMEs in a small economy: The world has become an increasingly interwoven place and according to Francis Fukuyamone, one of the greatest sociologist of our times- never before in human history so many nations moved together towards market economy and there is growing recognition worldwide that SMEs have an important role to play in the present circumstances (Bhargava, 2004) and small businesses are often seen as the backbone of the private sector in the developing world. The importance of the SMEs for future economic development has been lately mentioned at different levels and reinforced in the budget speech 2008/2009. The government is taking various measures and initiatives to better assist the SME sector'.

According to the United Kingdom's Department for International Development: By following socially responsible practices, the growth generated by the private sector will be more inclusive, inequitable and poverty reducing' In its report the Mauritius Employers' Federation (March 2011) declared that Private enterprises in Mauritius have a long culture and tradition of CSR, particularly in terms of voluntary social engagement in the communities where they operate and in the wider society. Mauritian enterprises, driven primarily by ethical considerations, employee motivation, brand positioning and company reputation, have been engaged in both internal CSR, undertaken for the benefits of employees, and external CSR initiatives, developing or supporting social and community related activities'.

In a recent study, Ragodoo ${ }^{14}$ (2011) explained that: Business is very reluctant to provide funding to any NGO unless they are $100 \%$ confident that these NGOs are genuinely committed to serve. As a result, business generally opts to fund larger NGOs which have established procedures and a proper system of checks and balances that they trust rather than funding those who lack visibility. Inevitably, this is at the detriment of small NGOs which might be genuinely committed to help'. It is undeniable that high and sustainable economic growth and pro-poor targets can be achieved provided a country is internationally competitive and is politically stable which is not the case of most African countries. Thus, trade performance is significantly important determinant to economic growth, employment and livelihood creation and ultimately poverty reduction. Thus is not surprising that Mauritius has taken key steps to ensure that intra-regional and international trade are strengthened through a relevant national policy framework (fiscal policy, Mauritius Duty Free Island, Mauritius Duty Free Paradise), new strategies, plans, innovations, legal and institutional frameworks (i.e. the Board of Investment, MEDIA for export promotion) have been earmarked for promoting business and trade. As Ali Mansoor ${ }^{15}$ rightly pointed out that: 'In fact economic growth has enabled a number of countries like India, Uganda, Brazil, Vietnam and Tunisia to reduce their overall poverty levels and offer wider opportunities to the people. Over recent decades, China has experienced rapid growth of around $8 \%$ annually, resulting in a marked improvement in its Human Development Index, which has increased from a low of 0.560 in 1980 to 0.768 in 2004'.

Is there a relation environment-trade and poverty? The relation environment-trade has long been forgotten though they have very strong links. Some African countries including Mauritius have implemented a large number of legislations and have ratified a large number of treaties and conventions to protect their environment for a better and a more appropriate sustainable development. They are now more prepared to any unforeseen impacts such as climate change, terrorism or environmental

\footnotetext{
${ }^{12}$ Rosunee S. 1990, The Mauritian textile and clothing industry: facing t5he challenges associated with globalization, infd.org/events/wfsids/virtual/papers

${ }^{13}$ Padachi K. 2009, Accounting services among manufacturing SMEs: a neglected subject

${ }^{14}$ Ragodoo J-F N. 2011, The Mauritian business sector and the fight against poverty: a NGO's perspective. Social Responsibility Journal , Vol. 7, No.2, pp.152-165

${ }^{15}$ Mansoor A. 2008, Macro-economic policy-making and poverty in Mauritius in Poverty in Mauritius-An agenda for reflection and action: articulating the local and the regional-conference papers, Caslon Printing Ltd, Republic of Mauritius
} 
degradation provoking irreversible damages to the environment provoking chaos and disorder to the very fragile economy of many African countries. It is important to understand that because of industrial and agricultural development there are various land-based activities, which occur mainly from domestic sewage, air and water pollution. Shall there be any environmental aim at safeguarding the marine and land environment humanity will have to pay for it.

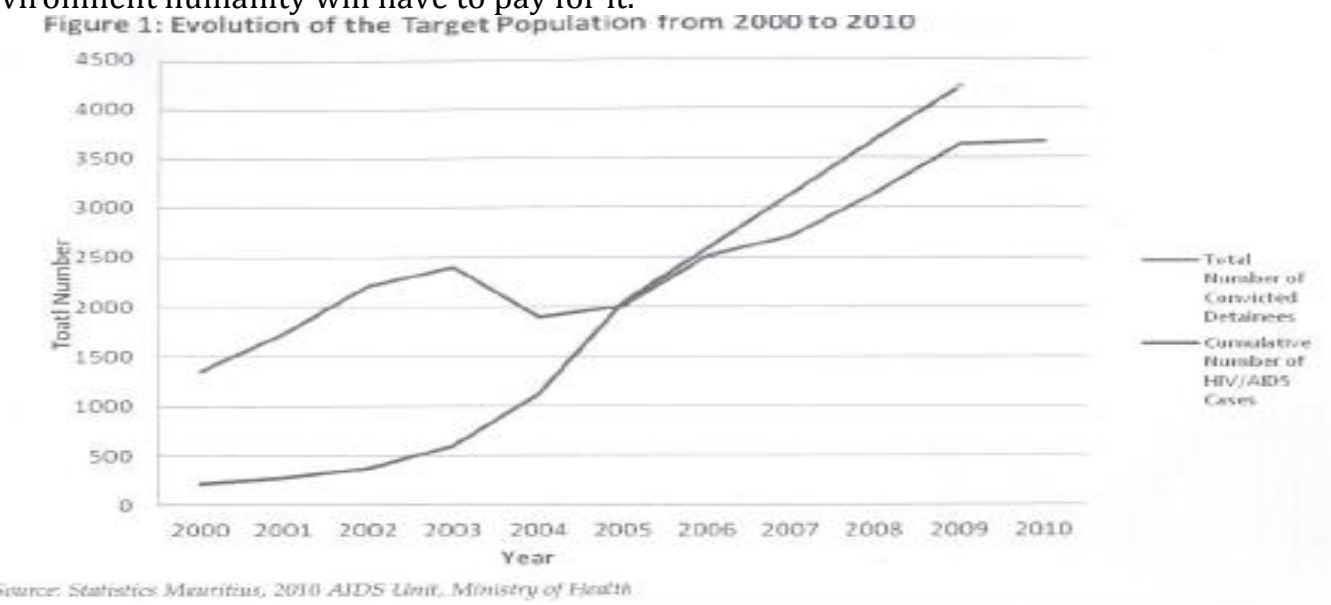

In the same line water pollution and diseases (cholera and HIV AIDS will contaminate million of people and other visceral disease will kill men, women and children on the African continent) eventually discourage potential investors to trade in Africa. In Mauritius, there are controls on the borders (Figure 3 below) and the disease is on the decrease after a peak in 2006. Ritter16 explained in his research that: 'As we all know the HIV pandemic started decades ago around the Lake Victoria making the Sub-Saharan region and principally the Southern and Eastern part of Africa the most affected area of the African continent. While Sub-Saharan African countries represent $10 \%$ of world population they cover $60 \%$ of the world population of People Living with HIV/AIDS and represents more than $70 \%$ of global AIDS death. Life expectancy has dropped up to 20 years in the most affected countries and between 1990 and 2003 the Human Development Index lost 35 points in South Africa, 23 in Zimbabwe , 21 in Botswana, 20 in Swaziland, 18 in Kenya and 16 in Zambia, mainly due to the impact of HIV/AIDS'.

Figure 3: Modes of Transmission for New HIVIAIDS Cases

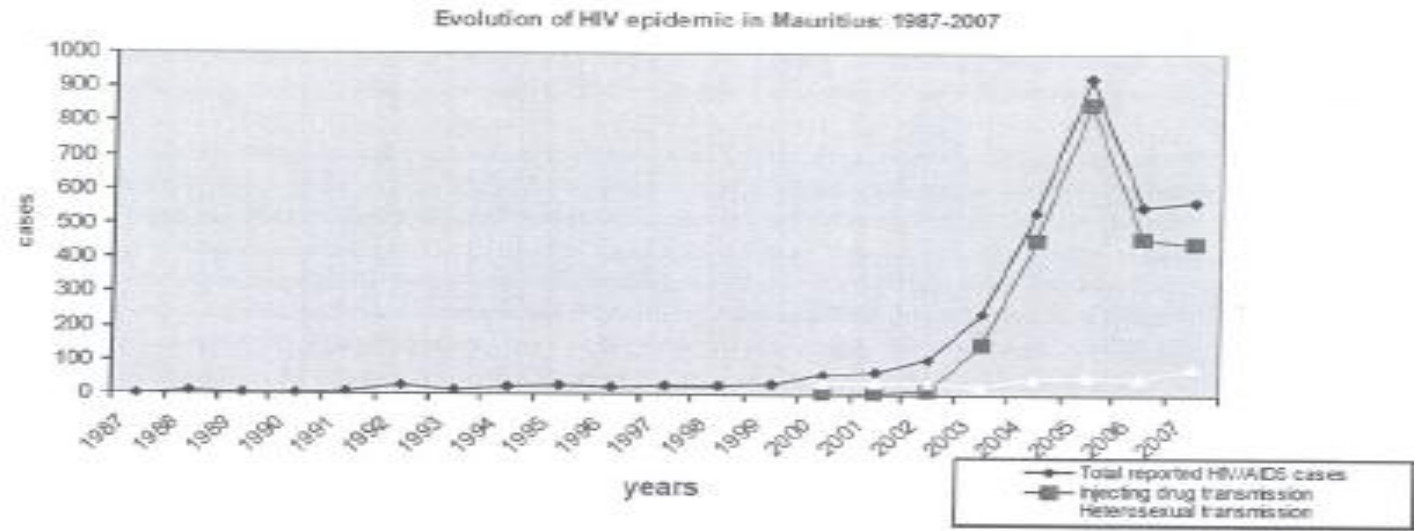

Water will be very scarce in Africa and dead cattles will litter valleys where pastoralists are murdered for their water. Ethnical conflicts and community conflicts are thus inevitable for a poorer Africa. Imagine now how environmental refugees and internally displaced persons are going to suffer? Climate change will inevitably provoke a sea rise and will add to calamities and other natural disasters reducing the world production by $10 \%$ for maize production, which is important for Africa and maybe sorghum will be reduced as well. Bangladesh, during the floods, had their crops destroyed by $80 \%$ and around 0 million people were homeless. Africa needs to protect its environment. Today, though we believe in life before death trade in Africa will be jeopardised if lagoons are empty, plantations are destroyed by natural

\footnotetext{
${ }^{16}$ Ritter 2008, HIV \& Poverty- A challenge for Mauritius and the Region, p. 167, Caslon Printing Ltd, Mauritius
} 
disasters or Africa become insecure with violent non-State actors. It is time to react and to react promptly.

Innovations and Projects Development for Trade: Research must be innovative. Apart from government policies and far from international funding any African citizen must be able to innovate and look for ideas for his own welfare. In fact, he was must be independent. Nobody prevents him for doing so. There are so many ideas and ways to obtain a decent living and with a decent job without relying on the public or private sector. Unemployment is high is Africa. Many graduates are unemployed while they have so much to offer and they have the knowledge and the know-how to be good entrepreneurs. There are huge opportunities in Africa but most of them are unexploited.

There are various innovations and projects for development for trade. Poverty is the new scourge for the African continent.

Corruption, illiteracy, climate change, droughts, floods, gender inequality, political instability, lack of new and appropriate government policies for trade and development, crime, murder, rape, HIV-AIDS, are challenges to poverty eradication which will eventually weaken trade and business in the country and with foreign countries. Motivated investors may found it difficult to invest in a country where there are such negative impacts on the economy of a country. Is the following list a sufficient food for thought?

- Fabrication of solar cells

- Fabrication of furniture for exportation (Gabon)

- Fabrication of CDs

- Fish farming and poultry farming must be encouraged to fight against unemployment, increase production, reduce competition and monopoly and a reduction of price shall be beneficial to one and all

-African government must control mining of precious metals and exportation. Illegal exportation is encouraging corruption among members of the government.

Murder is frequent and there is a loss of income for the country. There are a lot of traffics in Africa across the borders. The exploitation of precious metals in ex Zaire has been a blunder and more than a massacre. Acres of land were given to any citizen who wants to dig and find precious metals while the ecosystem got very severe damages. Instead, exploitation of precious metals must have been under the control of the State just like in South Africa. African States must have a control their mines and to control their exportation for their own welfare.

- Illegal imports are overlooked on the frontiers by corrupted officers thus reducing the income of the country

- Encourage local entrepreneurs to merge for clustering. Their products may easily be patented and sold in other countries. African banks must provide loan to entrepreneurs to stimulate entrepreneurship.

- There is oil in Africa (Sahara desert, Nigeria, Niger) and is under exploited. Experts must be sent on the field to look for oil. Oil prices and its regular fluctuations are affecting the Mauritian economy. Air Mauritius, the national air company, spend some 7,7 billion Euros for its petrol. African countries must produce their oil and they have the potential to do better and the best is not yet to come.

- African brains are running away to settle abroad sharing their knowledge with rich and industrial countries. They must be encouraged to settle in their own countries after their studies.

- Pharmaceutical products and their exportation generate a lot of income for a country. However, none of the African countries are exporting pharmaceutical products. In fact they are importing expensive pharmaceutical products and the price is still climbing exponentially in many drug houses. Now with HIVS AIDS, many African countries are spending a huge amount of money to treat patients. They must be treated but prevention is better than care. Mauritius is exporting medicine and other pharmaceutical products to some African countries (Madagasgar, Gabon, Cameroon,

Mozambique, Rwanda, Burkina Faso) generating some Rs6 million to the country. The production is still on the increase.

- African countries must open their markets and to encourage trade liberalisation. A good model is China and it is still expanding.

-Textile, clothing, jewellery and fish processing. Mauritius is importing its beef from Australia and flour from China while some African countries could have been its producers.

-Islamic Banking. For trade and to encourage investors it is also recommended to create a banking sector. Wherever banking sectors have been created it is found that

there are major developments. Islamic Banking (such as in Malaysia, Singapore, China) with its free interest may support African countries to development and trade

- African countries must try to develop key areas like the tourism sector and Freeport activities to support trade and business. To the exception of South Africa, most members of the SADV have not 
developed their harbours efficiently and consequently there is a lot of income. Modern hotels, Freeport and harbours need logistics and technology to survive in a global world. Most members of the SADC are still dependent on agricultural products. Agriculture contributes to 5\% of its GDP and 70\% of the SADC population still depends on this sector to have food, income and employment.

- African countries shall shift from primary and unfinished goods $(90 \%$ of the SADC exports comprise of mineral and agricultural goods) to manufacturing, services

and tourism sector. A reason why China is emerging in Asia is its ability to provide services and manufacturing goods. In addition to finished goods many spare parts are invading most markets of the world. They are sometime cheap but reliable.

- Africa must also rely on Africa. Mauritius has set up South African companies (supermarkets) in the country creating jobs and employment. As a result of trade with South Africa, the local economy envisaged a rapid boost in its financial and banking infrastructures. Many South African companies are mushrooming on the island.

- Banks must be able to give loans with low interest to promote trade and welfare of the citizens. In Mauritius, some banks have very low interest (5\% for this year, 2011).

- There shall be regular job and trade fair in Africa. They must be encouraged with support from the private sector, which is quite inexistent or latent in most African countries.

- Infrastructures (hotels, golf, administrative building, harbours, fish farming) on the east coast of the African continent, a zone ideal for trade and business, are very still poor.

- Development of its airports and harbours to encourage the tourism industry and to facilitate trade with neighbouring African countries.

Trade and Islamic Banking: a hope for a struggling Africa: To trade, one needs money. It goes without saying that most countries of the African continent are among the least developed countries in the world. Most Africans are still poor but they are still motivated to trade but prior to commencement business they need at least a minimum fund. They need funds prior to begin business and for a decent living but banks and other financial institutions are very reluctant to give loans to borrowers who in return have no assets (or very few) and have no property to be mortgaged especially at a time where more and more banks are less flexible unless they have imposed fixed and floating charges on their borrowers. To any problem there is always a solution and Islamic banking is a salvation to Mauritius. To improve trade on the African continent, bank interests (especially when they are high) are a poison to social-economic development and Islamic banking is the antidote. Most African countries are pressurized by the World Bank, IMF, endless recessions, international financial crisis, unemployment and poverty, climate change just to name a few. Interest-free banking is surviving in Sudan, Benin, Burkina Faso, Cameroon, Chad, Comoros, Djibouti, Egypt, Gabon, Gambia, Mali, Niger, Senegal, Sierra Leone, Uganda and it is at its burgeoning state in Mauritius actually. Islamic finance is allowing local entrepreneurs to settle their own business creating jobs and employment in the country without having to rely on traditional banks. There are actually 265 Islamic banks in 51 countries, the total worth of their assets is in excess of $\$ 265$ billion and the annual growth rate of Islamic banking sector is around 16\%. These figures are very tentative and Mauritius has reacted prompted by amending its legislations (Registration Duty Act and the Land (Duties and Taxes) Act) to avoid double payment of registration and to encourage the settlement of Islamic banking in Mauritius because it encourages joint venture financing (musharaka) and profit sharing based relationship (mudarabah). Islamic banking is growing at a rate of $10-15 \%$ per annum and there are over 200 Islamic banks operating in 65 countries with a population of around 1.3 billion, Islamic banks' capital is USD 90 billion that is growing at the rate of $15 \%$ per annum (Pakistan Legal Decisions, 1992). In Mauritius, the Bank of Mauritius has set Guide line for Institutions conducting Islamic Banking Business.

In a nut shell, the following chronologies of events show the Mauritius exposure to Islamic finance since 1998 to 2011:

- 1998- Al Barakah Multi-purpose Co-operative Society Limited

- 1999- ALEEF incorporation

- 2005- Inaugural of Mauritius Islamic Finance Forum (MIFF) by the Islamic Cultural Centre

2005- Established of an Islamic Financial Services Committee run by the BOM ${ }^{17}$

2007-BOM entered in Associate Membership with IFSB ${ }^{18}$

2007- Amendment of the Banking Act

- 2008- BAI ${ }^{19}$ Takaful inauguration. Islamic banking week

\footnotetext{
${ }^{17}$ Bank of Mauritius

${ }^{18}$ International Financial Services Board.
} 
2008- Deliverance of Budgetary Speech to use Sukuk $k^{20}$

2008-Amendment of Public Debt Management Act

2008-BOM publication of the Guidelines for institutions conducting Islamic banking business

2009-Mauritius Leasing launched Ijarah²1

2009- HSBC22 launched Amanah current and investment accounts

2009-FSC admittance as Associate member of IFSB

2009-Granting the first Islamic banking licence to Century banking Corporation

2010-Publication of SP5/10 on VAT by MRA for 'Murabahah²'dealings

2010-BOM admittance as a full member of IFSB

2010-BOM became founder member of IILM

2010-BOM and Bank Negera Malaysia entered in a Memorandum of Understanding (MoU)

2011-Al Barakah Multi-purpose Co-operative Society Limited with Al Huda Centre of Islamic Banking and Economics from Pakistan organized an "International Conference on Islamic Banking and Finance in Mauritius" on $5^{\text {th }}$ and $6^{\text {th }}$ April 2011 at Gold Crest Hotel, Quatre-Bornes, Mauritius.

Facts and figures reflect to what extent Islamic banking is important. After only a few years of existence, there are actually 265 Islamic banks in 51 countries $^{24}$ and it has been found that the total worth of their assets is in excess of $\$ 265$ billion and the annual growth rate of the Islamic banking sector is around $16 \%$. It is also interesting to note that even in non-Muslim countries ${ }^{25}$, Islamic banks are operating efficiently and in perfect harmony with conventional banks. There is no reason why it should not be so. Should Islamic banking continues to progress financially or should it face obstacles such as international crisis? Whatsoever, McKinsey \& Co, a Management Consultant of universal reputation, has estimated the Islamic banking sector to reach $\$ 1$ trillion in assets by 2010. The growth of Islamic banking has been at an annual rate of $15 \%$ over the past five years and the current market size is estimated around US $\$ 70$ billion. It is expected that African countries shall take benefit of Islamic banking and countries (supra) which have done up so far are doing well, at least, in domestic trade and in some poor countries of Africa, farmers are still able to survive due to facilities afforded by Islamic banking.

\section{Recommendations}

The term 'trade' must not stand alone or work alone. Various branches such as education, management, skills, human development, ideas and innovations just to name a few must be linked with trade to yield the maximum in terms of import and export. After ministerial conferences and other committees ministers and their officials have assisted most countries unfortunately forgot their commitment and most recommendations are dead letter. There must be a sort of follow up so that policies are implemented, that governments are committed and honour their mandate. Trade is also very fragile. An increase in price of oil and petrol will cause domestic inflation. It was around $42 \%$ in Mauritius. Inflation affects tariff airfares, local consumption and even employment. Apart from economic diversification, Mauritius has tried to honour its obligations and to respect all dead line it has committed so far.

- Strategies and national policies emanating from the government and the private sector to develop, promote and encourage trade provided there are suitable and efficient institutions to give managerial and

\footnotetext{
${ }^{19}$ British American Insurance

${ }^{20}$ Sukuk (Islamic bonds) or securitized credit finance is the most dynamic instrument for capital mobilisation and has the same financial characteristics as conventional bonds and notes but the only difference is that all legal contracts must have been approved by sha'riah law.

${ }^{21}$ Ijara (or leasing) in Islamic law requires any Islamic bank (as lessor) to purchase the property of a person (homeowner or lessee) who will reside as a tenant over a specific period of time. He pays a fixed rent until he owns the asset. Ijarahis similar to conventional leasing with a lessor and lessee but the only difference with Islamic law or Sha'riais that any Islamic bank may sell back the property at its original purchase price rather than its market value at the time of the sale.

${ }^{22}$ Hong Kong and Shanghai Banking Corporation

${ }^{23}$ Murabahah (or cost-plus) in Islamic law requires an Islamic bank to purchase commodities and to sell them at a predefined mark-up price. The client signs a 'promise to purchase' agreement with the bank before the latter purchases the property but the Islamic institution cannot earn excessive profits from the client. In the UK, Natwest has launched the Alif Baa Taa, a commercial finance based on Murabaha along with the Bank of Ireland.

${ }^{24}$ Afghanistan, Albania, Algeria, Azerbaijan, Bahrain, Benin, Brunei, Burkina Faso, Cameroon, Chad, Comoros, Djibouti, Egypt, Gabon, Gambia, Guinea, Indonesia, Iran, Iraq, Kuwait, Lebanon, Maldives, Mali, Mauritania, Morocco, Niger, Oman, Pakistan, Qatar, Saudi Arabia, Senegal, Sierra Leone, Somalia, Sudan, Tunisia, Turkey, Uganda, UAEU, Yemen.

${ }^{25}$ UK and USA.
} 
administrative support. Mauritius is able to survive in a global economy due to a strong legal and institutional framework (supra).

- Trade requires less bureaucratic and structural bottlenecks especially when most African countries are relatively poor or least developed country in the world in terms of trade, importation, exportation of goods and materials capable of generating money in the country. In return they must have sufficient incentives to attract foreign investors but unfortunately this has not been the case in the last two decades.

- African countries shall promote the development of institutions to facilitate trade (such as the Board of Investment)

- Encourage clustering of SMEs in the sub-Saharan region

- African countries must improve their technology and logistics, which are important for the creation of new skills. Hire purchase, leasing and factoring are means where entrepreneurs may receive funds to begin business and purchase the materials they need

-Development in infrastructures focusing on primary, secondary and tertiary institutions, which are capable to do research, and innovations. The University of Mauritius is often contacted for researches in tourism, solar energy and sustainable development for a cleaner and better Mauritius. Most researches, which have been carried out by local academics, have been successful both locally and abroad

- Training of young entrepreneurs either to run their own businesses as SMEs or to join other entrepreneurs is important for Africa today. Clustering is encouraged

- The economic partnership agreements cover millions of people, it is easy to trade in an unfair manner at the expense of others inventions and to make money. Infringements to trade marks, patents and copyright destroy the good economy of a country.

- African countries should avoid focusing on too much trade. Instead, it is advisable to pin point specific areas and markets where a country is more performant. Mauritius is targeting three main industries actually (tourism, tuna and fish industry and the textile industry) with less interest in tobacco, tea or sugar. These industries are generating a large income to the country and SMEs seem to the next target.

- Members of the regional blocks shall not trade or live isolated. Though trade barriers have been removed exportation is relatively in the SADC/COMESA region. Mauritius has moved to a more outwardoriented policy, including trade liberalization. It is recommended that there are regular meetings between government officials to boost and enhance trade in the country. The Prime Minister of Mauritius has always been very active in promoting Mauritian's know-how to other countries (China, India, Reunion Island, Madagascar, Seychelles, South Africa, USA, England, and France), meeting officials and delegations accompanied by monitor progress made towards trade-hub. Most countries in the region are now looking to Mauritius with a view to trade. Exports in COMESA stood as Rs 15 million in 1985 and in 1998, Mauritius has been exporting goods worth some Rs 1.7 billion in that regional economic block. And there is more to come.

- There is development to be made urgently in the free port sector, offshore services sector and the tourism sector just to name a few.

- Apart from funds obtained from the government (the Developing Bank of Mauritius is very active in providing loans) businessmen and entrepreneurs must be capable of raising their own funds by creating public limited companies.

- The will for the EU-ACP to liberalize and enhance trade is here but the creation of various regional and sub-regional institutions may also provoke unnecessary and fair competition between the regional blocks, as there are unequal developments and capacity building in the sub-Saharan region and between members themselves

- Trade liberalization is a complex puzzle. All different pieces related to each other must bring their personal support and issues such as ozone depletion, trade in hazardous waste, trade in commodities, development in foreign investment, regulation of multinational enterprises must be developed and mastered to ensure there is peace and security in the country

- Save to some few exceptions (Nigeria, Zambia) African country must improve their technology transactions and to prepare themselves to promote new legislations to regulate and control transfer of technological transactions. In India, a pioneer in regulating technological transfer, there are the ImportExport Regulations Act 1948, Monopolies and Restrictive Trade Practices Act 1963, Industrial Development and Regulations Act just to name a few.

- Pharmaceutical products are relatively very expensive. Mauritius has imported \$650 million for the year 2002 whereas the pharmaceutical industry in Mauritius is still feasible in Mauritius and secondly African countries must import from China or India where expensive pharmaceutical products are less expensive. 
Conclusion: There is a 'big' hope to make Mauritius a 'tiger' in the Indian Ocean. Through curriculum development (in most modules in our tertiary institutions) the Mauritian government is also fighting hard to achieve sustainable development to preserve our fauna and flora, lagoons, natural reservoirs, wetlands just to name a few. It is also encouraging other African countries in trade with improvement in its textile and tourism sector. There is a massive redistribution of wealth, and unemployment (5\% to $8 \%$ recently) is still low but there is room for improvement especially in the SMEs sector, empowerment programme and corporate social responsibility. As a Welfare State, every individual in this country has access to free education (primary and secondary institutions) and fees at tertiary level is also low in order to give access to education to everybody and that there is at least a graduate per family. This is the policy of the actual government. In addition, all tertiary students have access to free transport. All these facilities are available because Mauritius had its economic miracle and its exportation is reasonably high but costs of labour and higher productivity were also instrumental to our economic development. Mauritius, according to the Financial Services Commission, also succeeded in attracting multinationals in settling up their holding companies in the offshore sector though money laundering and illicit money may slow down this attraction in Mauritius.

\section{References}

Hurbungs, S. (2008). An evaluation of the different poverty alleviation programmes in Mauritius, Caslon Printing Ltd, Mauritius

Joomun, G. (2006). Textile and clothing industry in sub-Saharan Africa, The future of the textile and clothing industry in sub-Saharan Africa (Bonn: Friedrich-Ebert-Stiftung).

Jeetah, R. (2005). Challenges facing the textile and apparel industry, Mauritius, workshop 2005

Mansoor A. 2008, Macro-economic policy-making and poverty in Mauritius in Poverty in Mauritius-An agenda for reflection and action: articulating the local and the regional-conference papers, Caslon Printing Ltd, Republic of Mauritius

Padachi, K. (2009). Accounting services among manufacturing SMEs: a neglected subject

Rosunee, S. (1990). The Mauritian textile and clothing industry: facing t5he challenges associated with globalization, infd.org/events/wfsids/virtual/papers.

Rosunee, S. (1990) The Mauritian textile and clothing industry: facing t5he challenges associated with globalization, infd.org/events/wfsids/virtual/papers

Rosunee, S. (1990). The Mauritian textile and clothing industry: facing t5he challenges associated with globalization, infd.org/events/wfsids/virtual/papers

Rosunee, S. (1990). The Mauritian textile and clothing industry: facing t5he challenges associated with globalization, infd.org/events/wfsids/virtual/papers

Ragodoo, J. F. N. (2011). The Mauritian business sector and the fight against poverty: a NGO's perspective. Social Responsibility Journal, 7(2), 152-165

Ritter, L. (2008). HIV \& Poverty- A challenge for Mauritius and the Region, p. 167, Caslon Printing Ltd, Mauritius 